Rev. IG, São Paulo, 4(1/2):25-51, jan./dez. 1983

\title{
GEOLOGIA DA FOLHA DE PIRAÇUNUNGA, SP
}

\section{Marcos MASSOLI *}

\begin{abstract}
RESUMO
A área mapeada situa-se no flanco leste da Bacia do Paraná. Apresenta uma coluna estratigráfica composta pelo Grupo Tatuí (siltitos, argilitos) e Formações Corumbataí (siltitos), Pirambóia (arenitos) e Piraçununga (areias), além de intrusões de diabásio e sedimentos quaternários (areias, argilas).

A Formação Piraçununga (Terciário) e o diabásio constituem aproximadamente $70 \%$ da área total; a Formação Corumbataí (Permiano) aflora na parte norte-nordeste da folha, estando recoberta pela Formação Piraçununga do lado da margem esquerda do rio Mogi Guaçu, desde Porto Ferreira até a altura da coordenada UTM 252 km; a Formação Pirambóia (Triássico) e o Grupo Tatuí (Permiano) são restritos à porção norte e sudeste, respectivamente; os depósitos quaternários constituem as planícies aluviais dos principais rios, como o Mogi Guaçu e o Jaguari Mirim (Fig. 1).
\end{abstract}

\section{ABSTRACT}

The mapped area lies on the Est border of the Paraná Basin. It presents a stratigraphic column formed by the Tatuí Group (siltite, claystone) and Corumbataí Formation (claystone), Pirambóia (sandstone) and Piraçununga (sand), beyond the diabase and quaternary sediments (sand, clay).

The Piraçununga Formation (Tertiary) and the diabase constitute mainly $70 \%$ of the total area. The Corumbataí Formation (Permian) cropsout the N-NE of the sheet, being covered by the Piraçununga Formation beside Rio Mogi Guaçu left bank, from Porto Ferreira to $252 \mathrm{~km}$ UTM coordinate. The Pirambóia Formation (Triassic) and the Tatuí Group (Permian) are limited to $\mathrm{N}$ and SE area respectively. The quaternary deposits constitute the principal rivers alluvial plains, like Mogi Guaçu and Jaguari Mirim (Fig. 1).

\section{INTRODUÇĀO}

A folha de Piraçununga situa-se na região leste-nordeste do Estado de São Paulo, estando compreendida entre os paralelos $21^{\circ}$ $45^{\prime}$ e $22^{\circ} 00^{\prime}$ e os meridianos $47^{\circ} 15^{\prime}$ e $47^{\circ}$ 30'. Dista $210 \mathrm{~km}$ de São Paulo pela rodovia Anhanguera.

O mapeamento dessa folha faz parte do Projeto de Levantamento Geológico de Formações de Superfície, escala 1: 50.000 , em desenvolvimento pelo Instituto Geológico. Esse projeto teve como área piloto a folha de Leme (FREITAS et alii, 1979).

A metodologia de trabalho consistiu em: 1 - detalhado levantamento de campo, auxiliado por fotointerpretação; 2 - coleta sistemática de amostras de rochas e solos (autóctones e/ou alóctones) para estudos sedimentológicos; 3 - sondagens a trado manual para verificação do comportamento granulométrico das unidades perfuradas, bem como determinação das espessuras dos solos que recobrem o substrato rochoso.

Dentre os trabalhos realizados na região, em escala de semidetalhe (1: 100.000), destacam-se os seguintes: MEZZALIRA (1965) e ANDRADE \& SOARES (1971).

\section{GEOMORFOLOGIA}

Conforme a divisão geomorfológica do Estado de São Paulo, proposta por ALMEIDA (1964), a folha de Piraçununga situa-se na Depressão Periférica, zona do Mogi Guaçu.

* Instituto Geológico - Caixa Postal 8772 - 01000 - São Paulo, SP, Brasil 
Grande parte da área caracteriza-se por apresentar uma topografia bastante suave, constituindo colinas levemente onduladas com amplitudes geralmente não superiores a $100 \mathrm{~m}$ e altitudes de até $650 \mathrm{~m}$. O substrato rochoso é constituído pela Formação Corumbataí e pelo Grupo Tatuí (este em pequena escala), recobertos pelos sedimentos cenozóicos da Formação Piraçununga (Fig. 2-a).

No trecho compreendido entre Santa Cruz das Palmeiras e a Cachoeira de Emas, a presença de diabásio não modifica a suavidade do relêvo, salvo localmente com a formação de morros isolados, como o Morro São Luís.

A parte norte-nordeste da folha, bastante afetada por falhamentos, apresenta relêvo mais acentuado, com morros sustentados por diabásio, cujos topos atingem até 800 $\mathrm{m}$ de altitude (Fig. 2-b-c). Morrotes alongados representando diques de diabásio ocorrem a sul-sudeste do distrito de Jacirendi, com altitudes máximas de $870 \mathrm{~m}$ (Fig. 2b-c).

A rede hidrográfica obedece a um padrão dendrítico em maior extensão, apresentando alta densidade na área de exposição da Formação Corumbataí. O rio Mogi Guaçu obedece a um controle estrutural, mostrando alinhamento principal NW-SE e secundário aproximadamente E-W, direção esta concordante com o traçado do rio Jaguari Mirim, seu afluente da margem direita. Os demais afluentes do rio Mogi Guaçu, tanto da margem direita como da esquerda, apresentam direção NE-SW notadamente nos seus médio e baixo cursos, o que representa um controle estrutural.

\section{ESTRATIGRAFIA}

Cerca de $70 \%$ da área estão representados por diabásio e pela Formação Piraçununga (Terciário).

Os sedimentos subjacentes ao Grupo Passa Dois, conforme a estratigrafia adotada pelo Instituto Geológico, compõem o Super Grupo Tubarão, constituído pelos Grupos Tatuí e Itararé. $\mathrm{Na}$ área em questão ocorre apenas o Grupo Ta ui, que ocupa a porção sudeste da folha at ś o ribeirão Feio, onde está interrompido por intrusão de diabásio.

A Formação Corumbataí (Grupo Passa Dois) aflora a norte-nordeste de Porto Ferreira e a norte-noroeste de Santa Cruz das
Palmeiras; está recoberta pelos sedimentos da Formação Piraçununga à margem esquerda do rio Mogi Guaçu, desde Porto Ferreira até Piraçununga, só aflorando nos vales.

A Formação Irati (Grupo Passa Dois) não aflora, porém acorre em subsuperfície.

A Formação Pirambóia (Grupo São Bento) ocorre no extremo norte da área, desde Jacirendi até o vale do rio Claro.

O Holoceno está representado pelas planícies aluviais dos rios Mogi Guaçu e Jaguari Mirim.

Grupo Tatuí

Caracteriza-se por apresentar siltitos argilosos e argilitos de cor marrom chocolate, maciços ou com acamamento plano-paralelo, contendo esparsos grânulos e seixos predominantemente de quartzo.

Ocorre na margem direita do rio Mogi Guaçu, desde o extremo sudeste da folha até o ribeirão Feio, onde é interrompido por diabásio. Os poucos afloramentos encontrados aparecem no leito do citado ribeirão, constituindo pequenas corredeiras.

O topo do Grupo ocupa altitudes de até $600 \mathrm{~m}$. Em subsuperfície, poços perfurados na Academia da Força Aérea e na cidade de Piraçununga atingiram arenitos nas cotas de $440 \mathrm{~m}$ e $500 \mathrm{~m}$, respectivamente (Fig. 3-b-d).

O solo de alteração das rochas do Grupo Tatuí tem cores avermelhadas, é argiloso, podendo ser confundido com a terra roxa, distinguindo-se desta pela insignificância de magnetita.

Formação Corumbataí

Os sedimentos dessa Formação são representados por siltitos e argilitos de cores rosadas, marrons, mais raramente esverdeadas, creme e acinzentadas, maciços ou com acamamento plano-paralelo, apresentando fraturamento conchoidal. Podem ocorrer intercalações de arenitos finos, argilitos e siltitos carbonáticos constituindo camadas centimétricas.

Em um afloramento situado a sudoeste da fazenda Santa Iria, município de Santa Cruz das Palmeiras, ocorrem diversos níveis milimétricos de argilito marrom apresentando gretas de contração (preenchidas por areia fina de cor creme), intercalados em siltitos da mesmo cor, evidenciando variações no clima pretérito, com épocas secas alternadas por períodos úmidos mais longos. Nesse local, situado na parte média da Formação (cota $680 \mathrm{~m}$ ), encontra-se um nível fossilí- 
fero nos siltitos contendo fragmentos de peixes. No canto noroeste da folha também ocorrem restos de peixes em siltitos acamados, porém situados no topo da Formação que está a $570 \mathrm{~m}$ de altitude.

$\mathrm{Na}$ parte nordeste da folha, próximo aos ribeirões Quebra Cuia e Tabaranas, são relativamente comuns ocorrências de coquinas constituindo blocos situados no topo da Formação Corumbataí, que atinge a cota de $800 \mathrm{~m}$.

A noroeste da área, próximo à cabeceira do córrego do Barreiro, há um jazigo fossilífero contendo moldes de conchas lamelibrânquios, preservados em uma camada de $30 \mathrm{~cm}$ de siltitos maciços, arenosos, a qual se acha intercalada em siltitos avermelhados, com acamamento plano-paralelo (MASSOLI, 1981). Essa ocorrência localiza-se no topo da Formação, na cota de $580 \mathrm{~m}$.

A Formação Corumbataí aflora principalmente na metade norte da folha, desde leste (folha de Casa Branca) até oeste (folha de Descalvado). Constitui uma faixa descontínua, devido a intrusão de diabásio, com largura maior a nordeste de Porto Ferreira (desde o rio Claro até o córrego Pedra de Amolar, ambos afluentes da margem direita do rio Mogi Guaçu).

Do lado da margem esquerda do rio Mogi Guaçu, sua ocorrência restringe-se localmente aos vales situados entre Porto Ferreira e Piraçununga, formando uma área limitada a leste aproximadamente na altura da coordenada UTM $252 \mathrm{~km}$. Nessa parte da folha a Formação Corumbataí está recoberta pelos sedimentos da Formação Piraçununga, continuando em subsuperfície para as folhas de Descalvado e Leme, situadas respectivamente a oeste e a sul da folha de Piraçununga. Em direção a leste provavelmente não ocorre subsuperficialmente na altura do córrego Batistela.

O contato da Formação Corumbataí com o Grupo Tatuí não se verifica na área porque entre essas unidades expõe-se extensa intrusão de diabásio.

A espessura aflorante da Formação Corumbataí atinge $130 \mathrm{~m}$ a noroeste de Santa Cruz das Palmeiras, diminuindo para $40 \mathrm{~m}$ a norte de Porto Ferreira; em subsuperfície tem $45 \mathrm{~m}$ em Porto Ferreira (Fig. 3-a) e 30 $\mathrm{m}$ em Piraçununga (Fig. 3-b).

A alteração das rochas da Formação produz solos síltico-argilosos, de cor marrom claro, com espessuras geralmente não superiores a $0,5 \mathrm{~m}$.

Do ponto de vista econômico, suas argilas são utilizadas como matéria prima na indústria cerâmica. Camadas carbonáticas ocorrem na área, porém constituindo pequenas espessuras que as tornam anti-econômicas. As litologias essencialmente síltico-argilosas tornam a Formação Corumbataí um mau aqüífero, de modo que qualquer perfuração visando a captação de água subterrânea deve atravessá-la totalmente, a fim de atingir litologias maís permeáveis.

Formação Irati

A Formação Irati não aflora na folha de Piraçununga, porém ocorre em subsuperfície, conforme atestam sondagens efetuadas em Porto Ferreira e Piraçununga, visando a captação de água subterrânea (Fig. 3-ab-c).

Na cidade de Porto Ferreira a Formação Irati foi atingida na cota de $495 \mathrm{~m}$ (MEZZALIRA, 1970; 1971); está representada por folhelhos pretos e calcários (Membro Assistência) contendo restos de Mesosaurus brasiliensis, com espessura de $2 \mathrm{~m}$. Sobreposta à Formação Irati está a Formação Corumbataí, representada por siltitos cinzentos fossilíferos (restos de peixes) encimados por siltitos avermelhados. Abaixo do Irati ocorre diabásio, o qual tanto pode estar intrusivo nesta formação como pode estar posicionado no contato Irati-Tubarão, já que a sondagem não atravessou todo o corpo básico (Fig. 3-a).

Nas sondagens realizadas em Piraçununga, duas delas atingiram a Formação Irati: na cidade a Formação ocorre no nível de $510 \mathrm{~m}$ e é constituída por $5 \mathrm{~m}$ de folhelhos e calcários do Membro Assistência (Fig. 3-b); no CIZIP constitui 2 níveis de folhelhos e calcários de 7 e $5 \mathrm{~m}$ de espessura nas cotas de $515 \mathrm{~m}$ e $505 \mathrm{~m}$, respectivamente (Fig. 2-a e 3-c) (MEZZALIRA, 1970; 1971).

Baseado nesses dados de sondagens verifica-se que o topo da Formação Irati mantém uma cota praticamente constante entre Piraçununga e Porto Ferreira (em torno de $500 \mathrm{~m}$ ), apesar da ocorrência de espessa intrusão de diabásio associada a essa Formação.

Formação Pirambóia

Restringe-se ao extremo noroeste e à parte norte da folha.

Constitui-se de arenitos finos a muito finos, cor predominàntemente rosada, sele- 
ção pobre a muito pobre, pouco argilosos, maciços ou com estratificações plano-paralelas e cruzadas.

Os melhores afloramentos da Formação encontram-se no vale do rio Claro e a sudeste do distrito de Jacirendi.

O contato com a Formação Corumbataí se faz normalmente através de falhas, as quais elevaram os blocos contendo os sedimentos permianos. Intrusões de diabásio posicionadas entre o Pirambóia e o Corumbataí ocorrem próximo ao rio Claro e a sul de Jacirendi.

A sudeste da cabeceira do córrego Santa Clara, na estrada de acesso à fazenda Maracaju, observa-se o contato Pirambóia-Corumbataí: na base ocorre siltito argiloso marrom passando a cinzento, sobrejacente ao qual há uma camada de regolito fóssil com $10 \mathrm{~cm}$ de espessura; esse regolito está sobreposto por arenito grosseiro passando a fino com estratificações cruzadas.

A espessura máxima aflorante da Formação Pirambóia atinge $120 \mathrm{~m}$ no arredores de Jacirendi.

Dada a sua constituição litológica comporta-se como um bom aquífero. $\mathrm{Na}$ região de Descalvado, poços perfurados nessa Formação apresentam vazões variando de 10.000 a $25.000 \mathrm{l} / \mathrm{h}$ para profundidades de até $150 \mathrm{~m}$.

\section{Intrusivas básicas}

O diabásio apresenta vasta área de exposição na folha de Piraçununga, notadamente no trecho compreendido entre Santa Cruz das Palmeiras e a Cachoeira de Emas, na margem direita do rio Mogi Guaçu; para oeste de Santa Cruz das Palmeiras, em direção a Porto Ferreira, ocorre diabásio até a altura do ribeirão dos Patos; prolonga-se para norte-noroeste da folha, aí estando associado a falhamentos .

O corpo intrusivo a sudoeste de Santa Cruz das Palmeiras apresenta forma de lacólito, cujo núcleo está representado, provavelmente, pelo Morro São Luís. Sua espessura, na cidade referida, é de $150 \mathrm{~m}$, conforme dados de sondagem aí realizada. Essa sondagem, realizada no Jardim São Carlos para captação de água subterrânea, atingiu a profundid ide de $235 \mathrm{~m}$, e sob o diabásio atravessou $85 \mathrm{~m}$ de sedimentos do Super Grupo Tubarão; a vazão foi insignificante.

No vale do rio Claro o diabásico constitui um "sill" com $70 \mathrm{~m}$ de espessura, in- trusivo na parte basal da Formação Pirambóia, que se estende para sudeste em direção à cabeceira do córrego Pedra de Amolar, onde atinge $100 \mathrm{~m}$ de espessura.

Em subsuperfície ocorrem espessas intrusões de diabásio nas cidades de Piraçununga e Porto Ferreira. Nesta, o topo do corpe intrusivo está na cota de $495 \mathrm{~m}$ e sua espessura é superior a $125 \mathrm{~m}$ (Fig. 3-a). Naquela, a altitude do topo do diabásio é de $600 \mathrm{~m}$ e a espessura $95 \mathrm{~m}$ (Fig. 3-b). Os poços tubulares perfurados nessas duas cidades deram vazões nulas.

No CIZIP, localizado cerca de $2,5 \mathrm{~km}$ a noroeste de Piraçununga, em área de exposição de diabásio, foi realizada uma sondagem que perfurou cerca de $110 \mathrm{~m}$ de diabásio intrusivo na Formação Irati (Fig. 2-a e 3-c). Nos testemunhos de sondagem foram encontrados xenólitos de granito inclusos no diabásio (MEZZALIRA, 1970).

Na Academia da Força Aérea, situada cerca de $10 \mathrm{~km}$ a nordeste de Piraçununga, uma sondagem atingiu o diabásio a $15 \mathrm{~m}$ da superfície (na cota de $585 \mathrm{~m}$ ), com 140 $\mathrm{m}$ de espessura, sobreposto a sedimentos pertencentes ao Super Grupo Tubarão (Fig. 2-c e 3-d).

Intrusões discordantes ocorrem a sul de Jacirendi, constituindo diques de diabásio salientes na topografia, com altitudes de até $870 \mathrm{~m}$, larguras de algumas dezenas de metros e extensões de até $5 \mathrm{~km}$, associados a falhamentos (Fig. 2-b).

Formação Piraçununga

Essa Formação (FREITAS et alii, 1979) ocupa boa parte da folha, principalmente do lado da margem esquerda do rio Mogi Guaçu; na margem direita desse rio, a lestenordeste de Porto Ferreira, recobre o alto dos interflúvios, desde o córrego do Barreiro até o córrego da Pedra de Amolar.

Caracteriza-se por constituir sedimentos inconsolidados, cor castanho claro, sem estruturas sedimentares, areno-argilosos, granulação variando entre as frações areia fina e silte grosso (com predomínio desta), muito pobremente selecionados. Na base apresenta, geralmente, uma linha de seixos ou cascalheira, com seixos de quartzo e quartzito e fragmentos de limonita, sobrepostos de forma discordante sobre a Formação Corumbataí. Localmente ocorrem camadas centimétricas de argilas e areias de cores amareladas e acinzentadas, respectivamente. 
Sua espessura é bastante variável, atingindo até $15 \mathrm{~m}$ em sondagens (Fig. 3-a-b-d).

O relêvo constituído por essa Formação é bastante característico, apresentando uma área quase plana com vales pouco profundos e encostas suaves (Fig. 2-a-c). A variação altimétrica é de 550 a $650 \mathrm{~m}$.

Depósitos Holocênicos

Os depósitos recentes constituem as planícies aluviais dos principais rios, como o Mogi Guaçu e o Jaguari Mirim. São representados por areias e argilas retrabalhadas não só das Formações sedimentares como do embasamento cristalino, onde os citados rios têm as suas nascentes. As areias são utilizadas na construção civíl e as argilas usadas como matéria prima principalmente na confecção de tijolos e telhas.

\section{ESTRUTURA}

$\mathrm{Na}$ porção oeste-sudoeste da folha, na margem esquerda do rio Mogi Guaçu, foi possível a determinação da atitude das camadas, tomando-se como referência o topo da Formação Irati obtido em sondagens. Essa Formação foi atingida nas sondagens de Porto Ferreira (Fig. 3-a), Piraçununga (Fig. 3-b) e na Estância Laranjal, município de Descalvado (MEZZALIRA, 1970; 1971). Aplicando-se a regra dos três pontos, obteve-se direção $\mathrm{N} 25^{\circ} \mathrm{W}$ e mergulho $1 / 2^{\circ}$ SW (Fig. 4).

Localmente as camadas da Formação Corumbataí podem apresentar mergulhos de até $5^{\circ} \mathrm{NW}$ e a noroeste da folha, próximo ao córrego do Barreiro, foram verificados mergulhos de até $3^{\circ} \mathrm{NE}$.

O norte da folha está afetado por falhamentos que atingem principalmente o contato entre as Formações Pirambóia e Corumbataí. A sudoeste de Jacirendi duas falhas com direções noroeste-sudeste e uma falha com direção aproximadamente norte-sul constituem um bloco levantado, representado pela Formação Corumbataí, com rejeito de $60 \mathrm{~m}$ (Fig. 2-b-c). Esse bloco foi de- nominado Horst de Santa Iria por ANDRA. DE \& SOARES (1971).

A nordeste da área outra falha com direção nordeste-sudoeste, preenchida por diabásio (Serra do Sertãozinho), elevou o bloco sudeste contendo a Formação Corumbataí, com rejeito da ordem de $80 \mathrm{~m}$ (Fig. 2-b).

No vale do rio Claro uma falha com direção noroeste-sudeste põe em contato as Formações Pirambóia e Corumbataí, com elevação do bloco sudoeste, o qual contém os sedimentos permianos; o rejeito é de aproximadamente $80 \mathrm{~m}$. Associados a esse falhamento ocorrem um dique, que preenche o plano de falha, e um "sill" intrusivo na Formação Pirambóia (Fig. 2-b).

O rio Mogi Guaçú segue nítido controle estrutural, com direção principal noroestesudeste e direção secundária leste-oeste. A elevação seria dos blocos nordeste e norte.

Por sua vez, o rio Jaguari-Mirim segue uma direção preferencial leste-oeste, com a porção da margem direita topograficamente mais elevada que a da margem esquerda, sugerindo elevação do bloco norte.

\section{SEDIMENTOLOGIA}

Neste trabalho foram utilizadas 46 amostras de superfície, das quais se determinaram suas composições granulométricas, classificação de Sheppard e os parâmetros de Folk e Ward (tabela 6). A Fig. 5 representa o mapa de localização das amostras, cuja distribuição por unidade geológica é a seguinte:

Formação Piraçununga .... 24 amostras Formação Pirambóia ..... 08 " Formação Corumbataí .... 09 " Grupo Tatuí .......... 05 ", TOTAL ... $\overline{46} \quad$,

\section{a) Composição Granulométrica}

A Tabela 1 mostra a distribuição percentual média das frações areia, silte e argila para cada unidade geológica.

Tabela 1

\begin{tabular}{|l|r|r|r|}
\hline unid. geol. $\%$ granul. & $\%$ areia & $\%$ silte & $\%$ argila \\
\hline F. Piraçununga & 67,03 & 7,43 & 25,52 \\
\hline F. Pirambóia & 82,22 & 8,09 & 9,68 \\
\hline F. Corumbataí & 17,60 & 36,34 & 46,05 \\
\hline Gr. Tatuí & 25,17 & 23,62 & 51,19 \\
\hline
\end{tabular}


b) Diâmetro Médio

A Tabela 2 apresenta a percentagem de amostras de cada unidade geológica confor-

me o valor de seu diâmetro médio em milímetros.

Tabela 2

\begin{tabular}{|l|c|r|r|r|r|r|r|r|}
\hline $\begin{array}{r}\text { diâm. médio } \\
\mathrm{mm}\end{array}$ & $\begin{array}{c}0,5 \\
\mathrm{a} \\
0,25 \\
\text { a.m. }\end{array}$ & $\begin{array}{c}0,25 \\
\mathrm{a} \\
0,125 \\
\text { a.f. }\end{array}$ & $\begin{array}{c}0,125 \\
\mathrm{a} \\
0,062 \\
\text { a.m.f. }\end{array}$ & $\begin{array}{c}0,062 \\
\mathrm{a} \\
0,031 \\
\text { s.gr. }\end{array}$ & $\begin{array}{c}0,031 \\
\mathrm{a} \\
0,016 \\
\text { s.m. }\end{array}$ & $\begin{array}{c}0,016 \\
\mathrm{a} \\
0,008 \\
\text { s.f. }\end{array}$ & $\begin{array}{c}0,008 \\
\mathrm{a} \\
0,004 \\
\text { s.m.f. }\end{array}$ & arg. \\
\hline F. Piraçununga & 0,0 & 8,3 & 8,3 & 75,0 & 8,3 & 0,0 & 0,0 & 0,0 \\
\hline F. Pirambóia & 0,0 & 50,0 & 25,0 & 25,0 & 0,0 & 0,0 & 0,0 & 0,0 \\
\hline F. Corumbataí & 0,0 & 0,0 & 0,0 & 11,1 & 0,0 & 66,6 & 22,2 & 0,0 \\
\hline Gr. Tatuí & 0,0 & 0,0 & 0,0 & 0,0 & 0,0 & 60,0 & 40,0 & 0,0 \\
\hline
\end{tabular}

c) Desvio Padrão $(\sigma \mathrm{I})$

$\mathrm{Na}$ Tabela 3 representa-se o desvio padrão em percentagens de amostras por uni-

dade geológica, obedecendo-se os limites estabelecidos por Folk e Ward.

Tabela 3

\begin{tabular}{|l|r|c|c|c|c|c|}
\hline unid. geol. & $\begin{array}{r}0,35 \\
\text { m.b.s. }\end{array}$ & $\begin{array}{c}0,35-0,50 \\
\text { b.s. }\end{array}$ & $\begin{array}{c}0,50-1,00 \\
\text { mod.s. }\end{array}$ & $\begin{array}{c}1,00-2,00 \\
\text { p.s. }\end{array}$ & $\begin{array}{c}2,00-4,00 \\
\text { m.p.s. }\end{array}$ & $\begin{array}{c}>4,00 \\
\text { e.m.s. }\end{array}$ \\
\hline F. Piraçununga & 0,0 & 0,0 & 0,0 & 4,2 & 95,8 & 0,0 \\
\hline F. Pirambóia & 0,0 & 0,0 & 0,0 & 50,0 & 50,0 & 0,0 \\
\hline F. Corumbataí & 0,0 & 0,0 & 0,0 & 55,5 & 44,5 & 0,0 \\
\hline Gr. Tatuí & 0,0 & 0,0 & 0,0 & 0,0 & 100,0 & 0,0 \\
\hline
\end{tabular}

d) Assimetreia ( $\left.\mathrm{SK}_{\mathrm{I}}\right)$

Representa-se a assimetria na Tabela 4, em percentagens de amostras por unidade

geológica, conforme os limites de Folk e Ward.

Tabela 4

\begin{tabular}{|c|c|c|c|c|c|}
\hline unid. geol. & $\begin{array}{c}-1,00 \\
a \\
-0,30 \\
\text { m. negat. }\end{array}$ & $\begin{array}{l}-0,30 \\
\quad \mathrm{a} \\
-0,10 \\
\text { negat. }\end{array}$ & $\begin{array}{c}-0,10 \\
a \\
0,10 \\
\text { apr. sim. }\end{array}$ & $\begin{array}{c}0,30 \\
a \\
0,30 \\
\text { posit. }\end{array}$ & $\begin{array}{c}0,30 \\
\text { a } \\
1,00 \\
\text { m. posit. }\end{array}$ \\
\hline F. Piraçununga & 0,0 & 4,2 & 0,0 & 0,0 & 95,8 \\
\hline F. Pirambóia & 0,0 & 0,0 & 0,0 & 12,5 & 87,5 \\
\hline F. Corumbataí & 33,3 & 33,3 & 22,2 & 0,0 & 11,1 \\
\hline Gr. Tatuí & 80,0 & 20,0 & 0,0 & 0,0 & 0,0 \\
\hline
\end{tabular}

e) Curtose (KG)

Este parâmetro está representado na Tabela 5 , em percentagens de amostras por unidade geológica, segundo os limites estabelecidos por Folk e Ward. 
Tabela 5

\begin{tabular}{|c|c|c|c|c|c|c|}
\hline KG & $\begin{array}{l}0,067 \\
\text { m. plat. }\end{array}$ & $\begin{array}{c}0,67 \\
\text { a } \\
0,90 \\
\text { plat. }\end{array}$ & $\begin{array}{c}0,90 \\
\text { a } \\
1,11 \\
\text { mesoc. }\end{array}$ & $\begin{array}{l}1,11 \\
\text { a } \\
1,50 \\
\text { lept. }\end{array}$ & $\begin{array}{c}1,50 \\
\text { a } \\
3,00 \\
\text { m. lept. }\end{array}$ & extr. lept. \\
\hline F. Piraçununga & 54,1 & 16,6 & 0,0 & 0,0 & 29,1 & 0,0 \\
\hline F. Pirambóia & 0,0 & 0,0 & 0,0 & 12,5 & 37,5 & 50,0 \\
\hline F. Corumbataí & 33,3 & 22,2 & 11,1 & 11,1 & 22,2 & 0,0 \\
\hline Gr. Tatuí & 60,0 & 40,0 & 0,0 & 0,0 & 0,0 & 0,0 \\
\hline
\end{tabular}

f) Sedimentogramas

Os sedimentogramas (FREITAS, 19731982) são gráficos que permitem uma visualização da distribuição granulométrica de um conjunto de amostras de uma determinada unidade geológica.

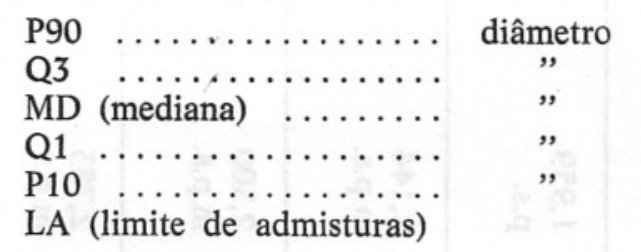

Na Tabela 7 encontram-se os valores dos percentis utilizados na elaboração dos sedimentogramas.

$\mathrm{O}$ intervalo compreendido entre $0 \%$ e $\mathrm{P} 90$ denomina-se cauda grossa, correspondendo a $10 \%$ em peso da amostra. O intervalo entre P90 e Q3 corresponde a $15 \%$ em peso e representa a fração grossa. A porção compreendida entre Q1 e Q3 corresponde às admisturas (grossa e fina) correspondendo a $50 \%$ em peso da amostra. O intervalo entre Q1 e P10 representa $15 \%$ em peso, sendo denominado fração fina. A parte compreendida entre P10 e $100 \%$ representa a cauda fina, equivalendo a $10 \%$ em peso da amostra.

O sedimentograma do Grupo Tatuí (Fig. 6) mostra o intervalo entre Q1 e Q3 bastante amplo, abrangendo pelo menos 5 classes texturais, o que indica uma má seleção entre esses dois percentis. A mediana tende para o lado do silte fino e argila grossa, estando afastada do limite das admisturas. A fração fina mantém-se constante, ocupando o intervalo correspondente à fração argila, o que significa que a porção situada à direita de Q1 e que corresponde a $25 \%$ da amostra, apresenta $25 \%$ de argila, ao passo que os $75 \%$ restantes são compostos por areia, silte e argila. A parte situada à es-
Os sedimentogramas são construídos a partir de percentis obtidos das curvas de frequêencia acumulativa das amostras, sendo representados por:

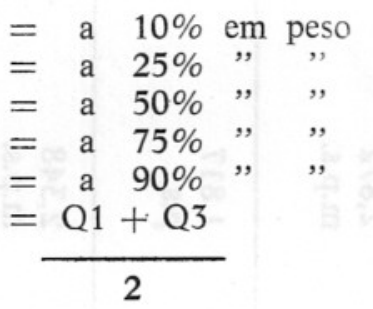

querda de Q3 e equivalente a $25 \%$ da amostra, varia de silte grosso a areia fina: a amostra 113 , por exemplo, apresenta $25 \%$ de areia (fina e média) e $75 \%$ de areia, silte e argila, de maneira que a percentagem em areia é superior a $25 \%$, o mesmo acontecendo com a amostra 77; as demais amostras têm menos que $25 \%$ de areia.

O sedimentograma da Formação Corumbataí (Fig. 7) mostra um intervalo textural Q1-Q3 pouco menor que o do Grupo Tatuí. Tal intervalo abrange as frações silte e argila, com exceção da amostra 24-A onde avança para a areia muito fina, fazendo com que essa amostra seja única a ter mais de $25 \%$ de areia em sua composição granulométrica. A mediana é variável entre a argila grossa e silte médio, apresentando valores semelhantes aos encontrados para o Grupo Tatuí. O percentil Q3 mostra valores variando desde silte muito fino a areia muito fina, o que indica que a fração grossa da Formação Corumbataí apresenta uma granulação inferior à da fração grossa do Grupo Tatuí. O percentil Q1 mantém-se entre a argila média e grossa, mostrando que as frações finas do Tatuí e da Formação Corumbataí são semelhantes quanto à granulometria. 
Tabela 6

\section{CARACTERISTICAS DAS AMOSTRAS}

\begin{tabular}{|c|c|c|c|c|c|c|c|c|}
\hline amostra & unid. geol. & $\begin{array}{l}\% \text { areia } \\
\% \text { silte } \\
\% \text { argila }\end{array}$ & $\begin{array}{l}\text { class. de } \\
\text { Sheppard }\end{array}$ & $\begin{array}{l}\text { diâm. médio } \\
(\mathrm{mm})\end{array}$ & $\begin{array}{l}\text { grau de } \\
\text { seleção }\end{array}$ & assimetria & curtose & $\begin{array}{l}\text { altitude } \\
\text { (m) }\end{array}$ \\
\hline 1 & F. Piraçununga & $\begin{array}{r}79,29 \\
2,59 \\
18,14\end{array}$ & areia & $\begin{array}{l}0,058 \\
\text { s. grosso }\end{array}$ & $\begin{array}{l}\text { 2,872 } \\
\text { m.p.s. }\end{array}$ & $\begin{array}{l}0,618 \\
\text { m.posit. }\end{array}$ & $\begin{array}{l}2,176 \\
\text { m. lept. }\end{array}$ & 590 \\
\hline $2 \mathrm{~A}$ & F. Corumbataí & $\begin{array}{r}5,50 \\
69,05 \\
25,46\end{array}$ & $\begin{array}{l}\text { siltito } \\
\text { argiloso }\end{array}$ & $\begin{array}{l}0,012 \\
\text { s. fino }\end{array}$ & $\begin{array}{l}1,817 \\
\text { p.s. }\end{array}$ & $\begin{array}{l}0,091 \\
\text { apr.sim. }\end{array}$ & $\begin{array}{l}0,672 \\
\text { plat. }\end{array}$ & 560 \\
\hline $5 \mathrm{~A}$ & F. Corumbataí & $\begin{array}{l}17,97 \\
55,93 \\
26,10\end{array}$ & $\begin{array}{l}\text { siltito } \\
\text { argiloso }\end{array}$ & $\begin{array}{l}0,014 \\
\text { s. fino }\end{array}$ & $\begin{array}{l}2,348 \\
\text { m.p.s. }\end{array}$ & $\begin{array}{l}-0,025 \\
\text { apr.sim. }\end{array}$ & $\begin{array}{l}0,922 \\
\text { mesoc. }\end{array}$ & 630 \\
\hline 7 & F. Corumbataí & $\begin{array}{r}6,28 \\
51,12 \\
42,60\end{array}$ & $\begin{array}{l}\text { silte } \\
\text { argiloso }\end{array}$ & $\begin{array}{l}0,0083 \\
\text { s. fino }\end{array}$ & $\begin{array}{l}1,959 \\
\text { p.s. }\end{array}$ & $\begin{array}{r}-0,157 \\
\text { negat. }\end{array}$ & $\begin{array}{l}0,705 \\
\text { plat. }\end{array}$ & 590 \\
\hline 8 & F. Pirambóia & $\begin{array}{r}76,25 \\
16,25 \\
7,50\end{array}$ & arenito & $\begin{array}{l}0,101 \\
\text { a.m.fina }\end{array}$ & $\begin{array}{l}\text { 2,144 } \\
\text { m.p.s. }\end{array}$ & $\begin{array}{l}0,515 \\
\text { m.posit. }\end{array}$ & $\begin{array}{l}1,287 \\
\text { lept. }\end{array}$ & 690 \\
\hline 15 & F. Corumbataí & $\begin{array}{l}11,50 \\
18,56 \\
69,94\end{array}$ & $\begin{array}{l}\text { argilito } \\
\text { siltoso }\end{array}$ & $\begin{array}{l}0,005 \\
\text { s.m.fino }\end{array}$ & $\begin{array}{l}\text { 2,300 } \\
\text { m.p.s. }\end{array}$ & $\begin{array}{l}-0,592 \\
\text { m.negat. }\end{array}$ & $\begin{array}{l}1,526 \\
\text { m. lept. }\end{array}$ & 690 \\
\hline 24 & F. Piraçununga & $\begin{array}{l}62,31 \\
14,50 \\
23,20\end{array}$ & $\begin{array}{l}\text { areia } \\
\text { argilosa }\end{array}$ & $\begin{array}{l}0,045 \\
\text { s.grosso }\end{array}$ & $\begin{array}{l}2,783 \\
\text { m.p.s. }\end{array}$ & $\begin{array}{l}0,625 \\
\text { m.posit. }\end{array}$ & $\begin{array}{l}0,606 \\
\text { m. plat. }\end{array}$ & 625 \\
\hline $24 \mathrm{~A}$ & F. Corumbataí & $\begin{array}{r}29,18 \\
5,31 \\
65,51\end{array}$ & $\begin{array}{l}\text { argilito } \\
\text { arenoso }\end{array}$ & $\begin{array}{c}0,008 \\
\text { s.fino }\end{array}$ & $\begin{array}{l}2,902 \\
\text { m.p.s. }\end{array}$ & $\begin{array}{l}0,661 \\
\text { m.negat. }\end{array}$ & $\begin{array}{l}0,603 \\
\text { m. plat. }\end{array}$ & 625 \\
\hline
\end{tabular}




\begin{tabular}{|c|c|c|c|c|c|c|c|c|}
\hline amostra & unid. geol. & $\begin{array}{l}\% \text { areia } \\
\% \text { silte } \\
\% \text { argila }\end{array}$ & $\begin{array}{l}\text { class. de } \\
\text { Sheppard }\end{array}$ & $\begin{array}{l}\text { diâm. médio } \\
(\mathrm{mm})\end{array}$ & $\begin{array}{l}\text { grau de } \\
\text { seleção }\end{array}$ & assimetria & curtose & $\begin{array}{l}\text { altitude } \\
\text { (m) }\end{array}$ \\
\hline 28 & F. Pirambóia & $\begin{array}{r}88,39 \\
2,58 \\
9,03\end{array}$ & arenito & $\begin{array}{l}0,129 \\
\text { a.fina }\end{array}$ & $\begin{array}{l}1,170 \\
\text { m.p.s. }\end{array}$ & $\begin{array}{l}0,570 \\
\text { negat. }\end{array}$ & $\begin{array}{l}4,485 \\
\text { extr. lept. }\end{array}$ & 570 \\
\hline 29 & F. Pirambóia & $\begin{array}{r}72,16 \\
19,88 \\
7,95\end{array}$ & $\begin{array}{l}\text { arenito } \\
\text { siltoso }\end{array}$ & $\begin{array}{l}0,097 \\
\text { a.m.fina }\end{array}$ & $\begin{array}{l}1,667 \\
\text { m.p.s. }\end{array}$ & $\begin{array}{l}0,493 \\
\text { m.posit. }\end{array}$ & $\begin{array}{l}1,845 \\
\text { m. lept. }\end{array}$ & 750 \\
\hline 34 & F. Piraçununga & $\begin{array}{r}46,54 \\
9,43 \\
44,03\end{array}$ & $\begin{array}{l}\text { areia } \\
\text { argilosa }\end{array}$ & $\begin{array}{l}0,017 \\
\text { s.médio }\end{array}$ & $\begin{array}{l}2,834 \\
\text { m.p.s. }\end{array}$ & $\begin{array}{r}-0,145 \\
\text { negat. }\end{array}$ & $\begin{array}{l}0,566 \\
\text { m. plat. }\end{array}$ & 565 \\
\hline 35 & F. Piraçununga & $\begin{array}{r}84,01 \\
4,92 \\
11,07\end{array}$ & areia & $\begin{array}{c}0,149 \\
\text { a.fina }\end{array}$ & $\begin{array}{l}1,741 \\
\text { p.s. }\end{array}$ & $\begin{array}{l}0,391 \\
\text { m.posit. }\end{array}$ & $\begin{array}{l}2,539 \\
\text { m. lept. }\end{array}$ & 600 \\
\hline 36 & F. Corumbataí & $\begin{array}{r}1,67 \\
53,52 \\
44,81\end{array}$ & $\begin{array}{l}\text { siltito } \\
\text { argiloso }\end{array}$ & $\begin{array}{c}0,008 \\
\text { s.fino }\end{array}$ & $\begin{array}{l}1,869 \\
\text { p.s. }\end{array}$ & $\begin{array}{r}-0,108 \\
\text { negat. }\end{array}$ & $\begin{array}{l}0,601 \\
\text { m. plat. }\end{array}$ & 585 \\
\hline 39 & F. Pirambóia & $\begin{array}{r}87,87 \\
85,06 \\
7,08\end{array}$ & arenito & $\begin{array}{l}0,124 \\
\text { a.m.fina }\end{array}$ & $\begin{array}{l}1,128 \\
\text { p.s. }\end{array}$ & $\begin{array}{l}0,498 \\
\text { m.posit. }\end{array}$ & $\begin{array}{l}3,976 \\
\text { extr. lept. }\end{array}$ & 705 \\
\hline 40 & F. Corumbataí & $\begin{array}{r}8,95 \\
15,84 \\
75,22 \\
\end{array}$ & argila & $\begin{array}{l}0,003 \\
\text { s.m.fino }\end{array}$ & $\begin{array}{l}1,983 \\
\text { p.s. }\end{array}$ & $\begin{array}{l}-0,543 \\
\text { m.negat. }\end{array}$ & $\begin{array}{l}2,334 \\
\text { m. lept. }\end{array}$ & 640 \\
\hline 43 & F. Pirambóia & $\begin{array}{r}76,92 \\
4,62 \\
18,47 \\
\end{array}$ & areia & $\begin{array}{l}0,049 \\
\text { s.grosso }\end{array}$ & $\begin{array}{l}2,730 \\
\text { m.p.s. }\end{array}$ & $\begin{array}{l}0,605 \\
\text { m.posit. }\end{array}$ & $\begin{array}{l}2,001 \\
\text { m. lept. }\end{array}$ & 715 \\
\hline $53 \mathrm{~B}$ & F. Pirambóia & $\begin{array}{r}87,75 \\
6,12 \\
6,12 \\
\end{array}$ & arenito & $\begin{array}{l}0,138 \\
\text { a.fina }\end{array}$ & $\begin{array}{l}1,361 \\
\text { p.s. }\end{array}$ & $\begin{array}{l}0,245 \\
\text { posit. }\end{array}$ & $\begin{array}{l}3,496 \\
\text { extr. lept. }\end{array}$ & 660 \\
\hline $53 \mathrm{C}$ & F. Corumbataí & $\begin{array}{r}3,41 \\
52,56 \\
44,03 \\
\end{array}$ & $\begin{array}{l}\text { siltito } \\
\text { argiloso }\end{array}$ & $\begin{array}{c}0,008 \\
\text { s.fino }\end{array}$ & $\begin{array}{l}1,927 \\
\text { p.s. }\end{array}$ & $\begin{array}{r}-0,198 \\
\text { negat. }\end{array}$ & $\begin{array}{l}0,604 \\
\text { m. plat. }\end{array}$ & 660 \\
\hline
\end{tabular}


Tabela 6 (CONTINUAÇÃO)

\begin{tabular}{|c|c|c|c|c|c|c|c|c|}
\hline amostra & unid. geol. & $\begin{array}{l}\% \text { areia } \\
\% \text { silte } \\
\% \text { argila }\end{array}$ & $\begin{array}{l}\text { class. de } \\
\text { Sheppard }\end{array}$ & $\begin{array}{l}\text { diâm. médio } \\
(\mathrm{mm})\end{array}$ & $\begin{array}{l}\text { grau de } \\
\text { seleção }\end{array}$ & assimetria & curtose & $\begin{array}{l}\text { altitude } \\
(\mathrm{m})\end{array}$ \\
\hline 54 & F. Piraçununga & $\begin{array}{r}78,25 \\
4,35 \\
17,40\end{array}$ & areia & $\begin{array}{l}0,057 \\
\text { s.grosso }\end{array}$ & $\begin{array}{l}2,818 \\
\text { m.p.s. }\end{array}$ & $\begin{array}{l}0,640 \\
\text { m.posit. }\end{array}$ & $\begin{array}{l}2,176 \\
\text { m. lept. }\end{array}$ & 580 \\
\hline 56 & F. Piraçununga & $\begin{array}{r}62,15 \\
7,57 \\
30,28\end{array}$ & $\begin{array}{l}\text { areia } \\
\text { argilosa }\end{array}$ & $\begin{array}{l}0,035 \\
\text { s.grosso }\end{array}$ & $\begin{array}{l}2,690 \\
\text { m.p.s. }\end{array}$ & $\begin{array}{l}0,621 \\
\text { m.posit. }\end{array}$ & $\begin{array}{l}0,565 \\
\text { m. plat. }\end{array}$ & 600 \\
\hline 57 & F. Piraçununga & $\begin{array}{l}48,90 \\
13,53 \\
37,57\end{array}$ & $\begin{array}{l}\text { areia } \\
\text { argilosa }\end{array}$ & $\begin{array}{l}0,027 \\
\text { s.médio }\end{array}$ & $\begin{array}{l}2,669 \\
\text { m.p.s. }\end{array}$ & $\begin{array}{l}0,477 \\
\text { m.posit. }\end{array}$ & $\begin{array}{l}0,557 \\
\text { m. plat. }\end{array}$ & 590 \\
\hline 60 & F. Corumbataí & $\begin{array}{r}73,97 \\
5,21 \\
20,83\end{array}$ & $\begin{array}{l}\text { arenito } \\
\text { argiloso }\end{array}$ & $\begin{array}{l}0,052 \\
\text { s.grosso }\end{array}$ & $\begin{array}{l}2,803 \\
\text { m.p.s. }\end{array}$ & $\begin{array}{l}0,651 \\
\text { m.posit. }\end{array}$ & $\begin{array}{l}1,405 \\
\text { lept. }\end{array}$ & 560 \\
\hline 62 & F. Piraçununga & $\begin{array}{r}67,19 \\
7,29 \\
25,52\end{array}$ & $\begin{array}{l}\text { areia } \\
\text { argilosa }\end{array}$ & $\begin{array}{l}0,046 \\
\text { s.grosso }\end{array}$ & $\begin{array}{l}2,892 \\
\text { m.p.s. }\end{array}$ & $\begin{array}{l}0,571 \\
\text { m.posit. }\end{array}$ & $\begin{array}{l}0,576 \\
\text { m. plat. }\end{array}$ & 605 \\
\hline 69 & F. Pirambóia & $\begin{array}{r}79,53 \\
4,09 \\
16,38\end{array}$ & areia & $\begin{array}{l}0,044 \\
\text { s.grosso }\end{array}$ & $\begin{array}{l}2,489 \\
\text { m.p.s. }\end{array}$ & $\begin{array}{l}0,705 \\
\text { m.posit. }\end{array}$ & $\begin{array}{l}2,671 \\
\text { m. lept. }\end{array}$ & 750 \\
\hline 77 & Gr. Tatuí & $\begin{array}{l}30,29 \\
16,48 \\
53,23\end{array}$ & $\begin{array}{l}\text { argila } \\
\text { arenosa }\end{array}$ & $\begin{array}{l}0,009 \\
\text { s.fino }\end{array}$ & $\begin{array}{l}2,774 \\
\text { m.p.s. }\end{array}$ & $\begin{array}{l}-0,616 \\
\text { m.negat. }\end{array}$ & $\begin{array}{l}0,613 \\
\text { plat. }\end{array}$ & 565 \\
\hline 80 & F. Piraçunung? & $\begin{array}{r}71,67 \\
6,29 \\
22,03\end{array}$ & $\begin{array}{l}\text { areia } \\
\text { argilosa }\end{array}$ & $\begin{array}{l}0,053 \\
\text { s.grosso }\end{array}$ & $\begin{array}{l}2,932 \\
\text { m.p.s. }\end{array}$ & $\begin{array}{l}0,616 \\
\text { m.posit. }\end{array}$ & $\begin{array}{l}1,570 \\
\text { m. lept. }\end{array}$ & 590 \\
\hline 81 & F. Piraçununga & $\begin{array}{r}75,31 \\
2,96 \\
21,73\end{array}$ & areia & $\begin{array}{l}0,058 \\
\text { s.grosso }\end{array}$ & $\begin{array}{l}2,973 \\
\text { m.p.s. }\end{array}$ & $\begin{array}{l}0,616 \\
\text { m.posit. }\end{array}$ & $\begin{array}{l}1,570 \\
\text { m. lept. }\end{array}$ & 590 \\
\hline
\end{tabular}




\begin{tabular}{|c|c|c|c|c|c|c|c|c|}
\hline \multirow[t]{2}{*}{ amostra } & \multirow[t]{2}{*}{ unid. geol. } & \multirow{2}{*}{$\begin{array}{l}\% \text { areia } \\
\% \text { silte } \\
\% \text { argila }\end{array}$} & \multirow[t]{2}{*}{$\begin{array}{l}\text { class. de } \\
\text { Sheppard }\end{array}$} & \multirow[t]{2}{*}{$\begin{array}{l}\text { diâm. médio } \\
(\mathrm{mm})\end{array}$} & \multirow[t]{2}{*}{$\begin{array}{l}\text { grau de } \\
\text { seleção }\end{array}$} & \multirow[t]{2}{*}{ assimetria } & \multirow[t]{2}{*}{ curtose } & \multirow[t]{2}{*}{$\begin{array}{l}\text { altitude } \\
\text { (m) }\end{array}$} \\
\hline & & & & & & & & \\
\hline 84 & Gr. Tatuí & $\begin{array}{l}16,02 \\
51,04 \\
32,93\end{array}$ & $\begin{array}{l}\text { siltito } \\
\text { argiloso }\end{array}$ & $\begin{array}{l}0,011 \\
\text { s.fino }\end{array}$ & $\begin{array}{l}2,218 \\
\text { m.p.s. }\end{array}$ & $\begin{array}{r}-0,181 \\
\text { negat. }\end{array}$ & $\begin{array}{l}0,784 \\
\text { plat. }\end{array}$ & 530 \\
\hline 92 & F. Piraçununga & $\begin{array}{r}57,98 \\
8,75 \\
33,26\end{array}$ & $\begin{array}{l}\text { areia } \\
\text { argilosa }\end{array}$ & $\begin{array}{l}0,035 \\
\text { s.grosso }\end{array}$ & $\begin{array}{l}2,846 \\
\text { m.p.s. }\end{array}$ & $\begin{array}{l}0,517 \\
\text { m.posit. }\end{array}$ & $\begin{array}{l}0,579 \\
\text { m. plat. }\end{array}$ & 580 \\
\hline 94 & F. Piraçununga & $\begin{array}{r}65,13 \\
4,98 \\
29,89\end{array}$ & $\begin{array}{l}\text { areia } \\
\text { argilosa }\end{array}$ & $\begin{array}{l}0,047 \\
\text { s.grosso }\end{array}$ & $\begin{array}{l}\text { 3,022 } \\
\text { m.p.s. }\end{array}$ & $\begin{array}{l}0,564 \\
\text { m.posit. }\end{array}$ & $\begin{array}{l}0,557 \\
\text { m. plat. }\end{array}$ & 580 \\
\hline 96 & F. Piraçununga & $\begin{array}{r}57,95 \\
6,57 \\
35,48\end{array}$ & $\begin{array}{l}\text { areia } \\
\text { argilosa }\end{array}$ & $\begin{array}{l}0,039 \\
\text { s.grosso }\end{array}$ & $\begin{array}{l}2,988 \\
\text { m.p.s. }\end{array}$ & $\begin{array}{l}0,521 \\
\text { m.posit. }\end{array}$ & $\begin{array}{l}0,570 \\
\mathrm{~m} . \text { plat. }\end{array}$ & 570 \\
\hline 97 & F. Piraçununga & $\begin{array}{l}60,00 \\
20,00 \\
20,00\end{array}$ & $\begin{array}{l}\text { areia } \\
\text { argilosa }\end{array}$ & $\begin{array}{l}0,043 \\
\text { s.grosso }\end{array}$ & $\begin{array}{l}2,720 \\
\text { m.p.s. }\end{array}$ & $\begin{array}{l}0,529 \\
\text { m.posit. }\end{array}$ & $\begin{array}{l}0,800 \\
\text { plat. }\end{array}$ & 575 \\
\hline $98 \mathrm{~A}$ & F. Piraçununga & $\begin{array}{l}53,60 \\
10,31 \\
36,09\end{array}$ & $\begin{array}{l}\text { areia } \\
\text { argilosa }\end{array}$ & $\begin{array}{l}0,033 \\
\text { s.grosso }\end{array}$ & $\begin{array}{l}2,800 \\
\text { m.p.s. }\end{array}$ & $\begin{array}{l}0,558 \\
\text { m.posit. }\end{array}$ & $\begin{array}{l}0,575 \\
\text { m. plat. }\end{array}$ & 585 \\
\hline $99 \mathrm{~A}$ & F. Piraçununga & $\begin{array}{r}70,53 \\
5,67 \\
23,80\end{array}$ & $\begin{array}{l}\text { areia } \\
\text { argilosa }\end{array}$ & $\begin{array}{l}0,046 \\
\text { s.grosso }\end{array}$ & $\begin{array}{l}2,789 \\
\text { m.p.s. }\end{array}$ & $\begin{array}{l}0,626 \\
\text { m.posit. }\end{array}$ & $\begin{array}{l}0,786 \\
\text { plat. }\end{array}$ & 590 \\
\hline 105 & F. Piraçununga & $\begin{array}{r}65,44 \\
5,32 \\
29,24\end{array}$ & $\begin{array}{l}\text { areia } \\
\text { argilosa }\end{array}$ & $\begin{array}{l}0,048 \\
\text { s.grosso }\end{array}$ & $\begin{array}{l}2,988 \\
\text { m.p.s. }\end{array}$ & $\begin{array}{l}0,613 \\
\text { m.posit. }\end{array}$ & $\begin{array}{l}0,573 \\
\text { m. plat. }\end{array}$ & 595 \\
\hline 106 & F. Piraçununga & $\begin{array}{r}82,95 \\
5,39 \\
11,67\end{array}$ & areia & $\begin{array}{l}0,162 \\
\text { a.fina }\end{array}$ & $\begin{array}{l}2,023 \\
\text { m.p.s. }\end{array}$ & $\begin{array}{l}0,530 \\
\text { m.posit. }\end{array}$ & $\begin{array}{l}2,062 \\
\text { m. lept. }\end{array}$ & 610 \\
\hline
\end{tabular}


Tabela 6 (CONTINUAÇÃO)

\begin{tabular}{|c|c|c|c|c|c|c|c|c|}
\hline amostra & unid. geol. & $\begin{array}{l}\% \text { areia } \\
\% \text { argila } \\
\% \text { silte }\end{array}$ & $\begin{array}{l}\text { class. de } \\
\text { Sheppard }\end{array}$ & $\begin{array}{l}\text { diâm. médio } \\
(\mathrm{mm})\end{array}$ & $\begin{array}{l}\text { grau de } \\
\text { seleção }\end{array}$ & assimetria & curtose & $\begin{array}{l}\text { altitude } \\
\text { (m) }\end{array}$ \\
\hline 107 & Gr. Tatuí & $\begin{array}{l}19,45 \\
19,39 \\
61,16\end{array}$ & $\begin{array}{l}\text { argila } \\
\text { arenosa }\end{array}$ & $\begin{array}{l}0,007 \\
\text { s.m.fino }\end{array}$ & $\begin{array}{l}2,460 \\
\text { m.p.s. }\end{array}$ & $\begin{array}{l}-0,591 \\
\text { m.negat. }\end{array}$ & $\begin{array}{l}0,654 \\
\text { m. plat. }\end{array}$ & 580 \\
\hline 111 & F. Piraçununga & $\begin{array}{r}77,62 \\
8,70 \\
13,68\end{array}$ & areia & $\begin{array}{l}0,088 \\
\text { a.m.fina }\end{array}$ & $\begin{array}{l}2,545 \\
\text { m.p.s. }\end{array}$ & $\begin{array}{l}0,618 \\
\text { m.posit. }\end{array}$ & $\begin{array}{l}1,874 \\
\text { m. lept. }\end{array}$ & 600 \\
\hline 113 & Gr. Tatuí & $\begin{array}{l}37,31 \\
12,54 \\
50,15\end{array}$ & $\begin{array}{l}\text { argila } \\
\text { arenosa }\end{array}$ & $\begin{array}{l}0,011 \\
\text { s.fino }\end{array}$ & $\begin{array}{l}\text { 3,001 } \\
\text { m.p.s. }\end{array}$ & $\begin{array}{c}-0,638 \\
\text { m.negat. }\end{array}$ & $\begin{array}{l}0,603 \\
\text { m. plat. }\end{array}$ & 565 \\
\hline 114 & Gr. Tatuí & $\begin{array}{l}22,81 \\
18,68 \\
58,52 \\
\end{array}$ & $\begin{array}{l}\text { argila } \\
\text { arenosa }\end{array}$ & $\begin{array}{l}0,007 \\
\text { s.m.fino }\end{array}$ & $\begin{array}{l}2,526 \\
\text { m.p.s. }\end{array}$ & $\begin{array}{c}-0,595 \\
\text { m.negat. }\end{array}$ & $\begin{array}{l}0,656 \\
\text { m. plat. }\end{array}$ & 570 \\
\hline 118 & F. Piraçununga & $\begin{array}{r}65,03 \\
7,23 \\
27,73\end{array}$ & $\begin{array}{l}\text { areia } \\
\text { argilosa }\end{array}$ & $\begin{array}{l}0,040 \\
\text { s.grosso }\end{array}$ & $\begin{array}{l}2,705 \\
\text { m.p.s. }\end{array}$ & $\begin{array}{l}0,698 \\
\text { m.posit. }\end{array}$ & $\begin{array}{l}0,575 \\
\text { m. plat. }\end{array}$ & 600 \\
\hline 119 & F. Pirambóia & $\begin{array}{r}88,92 \\
6,15 \\
4,92\end{array}$ & arenito & $\begin{array}{l}0,143 \\
\text { a.fina }\end{array}$ & $\begin{array}{l}1,066 \\
\text { p.s. }\end{array}$ & $\begin{array}{l}0,439 \\
\text { m.posit. }\end{array}$ & $\begin{array}{l}4,356 \\
\text { extr. lept. }\end{array}$ & 570 \\
\hline 124 & F. Piraçununga & $\begin{array}{r}76,72 \\
3,49 \\
19,79 \\
\end{array}$ & areia & $\begin{array}{l}0,073 \\
\text { a.m.fina }\end{array}$ & $\begin{array}{l}3,135 \\
\text { m.p.s. }\end{array}$ & $\begin{array}{l}0,658 \\
\text { m.posit. }\end{array}$ & $\begin{array}{l}1,848 \\
\text { m. lept. }\end{array}$ & 590 \\
\hline 125 & F. Piraçununga & $\begin{array}{r}59,36 \\
5,81 \\
34,84 \\
\end{array}$ & $\begin{array}{l}\text { areia } \\
\text { argilosa }\end{array}$ & $\begin{array}{l}0,047 \\
\text { s.grosso }\end{array}$ & $\begin{array}{l}3,219 \\
\text { m.p.s. }\end{array}$ & $\begin{array}{l}0,488 \\
\text { m.posit. }\end{array}$ & $\begin{array}{l}0,598 \\
\text { m. plat. }\end{array}$ & 560 \\
\hline 127 & F. Piraçununga & $\begin{array}{r}68,91 \\
7,77 \\
23,32 \\
\end{array}$ & $\begin{array}{l}\text { areia } \\
\text { argilosa }\end{array}$ & $\begin{array}{l}0,056 \\
\text { s.grosso }\end{array}$ & $\begin{array}{l}2,996 \\
\text { m.p.s. }\end{array}$ & $\begin{array}{l}0,602 \\
\text { m.posit. }\end{array}$ & $\begin{array}{l}0,651 \\
\text { m. plat. }\end{array}$ & 530 \\
\hline 130 & F. Piraçununga & $\begin{array}{r}71,96 \\
5,10 \\
22,94\end{array}$ & $\begin{array}{l}\text { areia } \\
\text { argilosa }\end{array}$ & $\begin{array}{l}0,056 \\
\text { s.grosso }\end{array}$ & $\begin{array}{l}3,016 \\
\text { m.p.s. }\end{array}$ & $\begin{array}{l}0,589 \\
\text { m.posit. }\end{array}$ & $\begin{array}{l}0,684 \\
\text { plat. }\end{array}$ & 565 \\
\hline
\end{tabular}


Tabela 7

TABELA DO SEDIMENTOGRAMA

$\begin{array}{rcccccc}\text { Amostra } & \text { P90 } & \text { Q3 } & \text { LA } & \text { MD } & \text { Q1 } & \text { P10 } \\ 77 & 0,200 & 0,080 & 0,040 & 0,0035 & 0,0013 & 0,00074 \\ 84 & 0,115 & 0,040 & 0,021 & 0,0100 & 0,0024 & 0,00094 \\ 107 & 0,100 & 0,046 & 0,023 & 0,0027 & 0,0011 & 0,00070 \\ 113 & 0,270 & 0,140 & 0,070 & 0,0060 & 0,0013 & 0,00076 \\ 114 & 0,125 & 0,050 & 0,025 & 0,0029 & 0,0012 & 0,00070\end{array}$

Formação Corumbataí

$\begin{array}{ccccccc}\text { Amostra } & \text { P90 } & \text { Q3 } & \text { LA } & \text { MD } & \text { Q1 } & \text { P10 } \\ \text { 2A } & 0,056 & 0,042 & 0,023 & 0,0130 & 0,0039 & 0,00110 \\ 5 \mathrm{~A} & 0,150 & 0,045 & 0,024 & 0,0170 & 0,0035 & 0,00100 \\ 7 & 0,051 & 0,029 & 0,015 & 0,0072 & 0,0016 & 0,00080 \\ 15 & 0,080 & 0,007 & 0,004 & 0,0022 & 0,0010 & 0,00066 \\ 24 \mathrm{~A} & 0,220 & 0,080 & 0,040 & 0,0024 & 0,0011 & 0,00068 \\ 36 & 0,049 & 0,033 & 0,017 & 0,0070 & 0,0015 & 0,00076 \\ 40 & 0,050 & 0,004 & 0,002 & 0,0020 & 0,0009 & 0,00066\end{array}$

Formação Pirambóia

$\begin{array}{ccccccc}\text { Amostra } & \text { P90 } & \text { Q3 } & \text { LA } & \text { MD } & \text { Q1 } & \text { P10 } \\ 8 & 0,430 & 0,320 & 0,192 & 0,1650 & 0,0640 & 0,00640 \\ 28 & 0,230 & 0,190 & 0,142 & 0,1500 & 0,0940 & 0,04000 \\ 29 & 0,240 & 0,190 & 0,122 & 0,1250 & 0,0540 & 0,00960 \\ 39 & 0,220 & 0,180 & 0,132 & 0,1350 & 0,0840 & 0,03100 \\ 43 & 0,360 & 0,210 & 0,138 & 0,1250 & 0,0660 & 0,00150 \\ 53 \mathrm{~B} & 0,310 & 0,210 & 0,147 & 0,1400 & 0,0840 & 0,02600 \\ 69 & 0,240 & 0,180 & 0,124 & 0,1200 & 0,0680 & 0,00170 \\ 119 & 0,240 & 0,210 & 0,180 & 0,1650 & 0,1300 & 0,05400\end{array}$

Formação Piraçununga

$\begin{array}{ccccccc}\text { Amostra } & \text { P90 } & \text { Q3 } & \text { LA } & \text { MD } & \text { Q1 } & \text { P10 } \\ 24 & 0,340 & 0,210 & 0,107 & 0,1250 & 0,0048 & 0,00120 \\ 56 & 0,230 & 0,180 & 0,091 & 0,1000 & 0,0028 & 0,00100 \\ 57 & 0,220 & 0,150 & 0,076 & 0,0580 & 0,0019 & 0,00088 \\ 62 & 0,400 & 0,230 & 0,117 & 0,1200 & 0,0038 & 0,00110 \\ 80 & 0,450 & 0,280 & 0,144 & 0,1400 & 0,0080 & 0,00130 \\ 92 & 0,300 & 0,190 & 0,096 & 0,1000 & 0,0023 & 0,00092 \\ 94 & 0,430 & 0,260 & 0,131 & 0,1300 & 0,0027 & 0,00098 \\ 96 & 0,380 & 0,200 & 0,101 & 0,0860 & 0,0021 & 0,00088 \\ 97 & 0,340 & 0,190 & 0,150 & 0,0880 & 0,0110 & 0,00140 \\ 105 & 0,410 & 0,240 & 0,121 & 0,1400 & 0,0029 & 0,00100 \\ 118 & 0,240 & 0,190 & 0,096 & 0,1200 & 0,0031 & 0,00100 \\ 125 & 0,510 & 0,250 & 0,126 & 0,1250 & 0,0023 & 0,00090 \\ 127 & 0,460 & 0,270 & 0,137 & 0,1600 & 0,0050 & 0,00120\end{array}$


O sedimentograma da Formação Pirambóia (Fig. 8) é completamente diferente daqueles apresentados até então. $\mathrm{O}$ valor da mediana é pouco variável, mantendo-se praticamente dentro da classe da areia fina, acompanhando o limite das admisturas tanto à sua direita como à sua esquerda. $\mathrm{A}$ fração grossa é bastante homogênea, estando representada por no máximo duas classes texturais: areia média e fina, principalmente esta. O intervalo Q1-Q3 compreende no máximo três classes granulométricas, de areia muito fina e areia fina principalmente. O percentil Q1 é pouco variável correspondendo praticamente à areia muito fina. Já o valor de P10 é bastante variável, abrangendo desde a fração silte grosso até argila média, fazendo com que o gráfico da fração fina apresente extremidades pronunciadas voltadas para a cauda fina; quanto mais para a direita estiverem tais extremidades mais argilosas são a 43 e a 69 , que contém $10 \%$ de argila correspondentes à cauda fina e mais certa percentagem de argila contida na fração fina. Esta, por sua vez, é mal selecionada, em relação à fração grossa, podendo abranger até 5 classes texturais.

O sedimentograma da Formação Piraçununga (Fig. 9) apresenta alguma semelhança ao da Formação Pirambóia quanto à fração grossa e mediana: esta é pouco variável, concentrando-se nas classes areia fina e areia muito fina; aquela mostra boa seleção, apresentando não mais que duas classes texturais (areia fina e média, com predomínio desta). O intervalo Q1-Q3 é bastante amplo (o maior entre as unidades geológicas estudadas), portanto mal selecionado, abrangendo no mínimo 5 classes granulométricas. O percentil Q1 situa-se entre silte fino e argila grossa, de maneira que a fração fina contém silte e argila (amostras 97, 80, 127 e 24) ou só argila (as demais amostras), mostrando que os sedimentos da Formação Piraçununga têm uma percentagem relativamente alta de matriz argilosa.

\section{CONCLUSŌES}

$\mathrm{Na}$ folha de Piraçununga ocorrem: Grupo Tatuí; as Formações Corumbataí, Pirambóia e Piraçununga; intrusões de diabásio; e sedimentos holocênicos.

O Grupo Tatuí tem ocorrência restrita na área, sendo representado por sedimentos ar- gilo arenosos, de cor marrom, apresentando esparsos seixos ou grânulos de quartzo e rochas sedimentares. Apresenta, em geral, uma percentagem de silte menor que a de areia e de argila. $\mathrm{O}$ diâmetro médio predominante equivale ao da fração silte fino. Possui seleção muito pobre, assimetria muito negativa e curtose muito platicúrtica. $\mathrm{O}$ intervalo entre Q1 e Q3 é amplo, denotando mal selecionamento; a fração fina é pouco mais selecionada que a fração grossa; a mediana tende para o lado da fração fina, enquanto o limite de admisturas está afastado em direção à fração grossa.

A Formação Corumbataí constitui-se por siltitos argilosos e argilitos, de cores rosadas e marrons, acamados ou maciços, com níveis carbonáticos de cores acinzentadas e camadas fossilíferas de arenito argiloso de cor marrom claro. O diâmetro médio, a exemplo do Grupo Tatuí, corresponde à classe do silte fino. A seleção é pobre a muito pobre, assimetria muito negativa a negativa, enquanto a curtose varia de muito platicúrtica a muito leptocúrtica. A fração grossa tem granulometria um pouco menor que a da fração grossa do Grupo Tatuí, ao passo que a fração fina mantém-se na classe da argila (como no Tatuí). O intervalo entre Q1 e Q3 abrange até 7 classes texturais, sendo pouco menor que a do Grupo Tatuí. A mediana situa-se do lado do silte fino a argila grossa. A Formação Corumbataí aflora a norte-nordeste de Porto Ferreira e a norte-noroeste de Santa Cruz das Palmeiras, estando recoberta pelos sedimentos da Formação Piraçununga em quase toda a área situada do lado da margem esquerda do rio Mogi Guaçu, só aflorando nos vales. Apresenta espessura máxima de $130 \mathrm{~m}$ a noroeste de Santa Cruz das Palmeiras. Dentre os fósseis encontrados, destacam-se coquinas (no topo da formação), conchas de lamelibrânquios (no topo) e restos de peixes (parte média e topo). A variação altimétrica do topo da formação vai desde $580 \mathrm{~m}$ (a noroeste da folha) até $800 \mathrm{~m}$ (nordeste da folha).

A Formação Irati não aflora na área, porém ocorre em subsuperfície em Piraçununga e Porto Ferreira. Representa-se por intercalações de folhelhos e calcários (Membro Assistência) e sua espessura não ultrảpassa $12 \mathrm{~m}$. Ocorre sempre em contato com diabásio e sua cota de topo permanece pratica- 
mente constante (em torno de $500 \mathrm{~m}$ ) nas duas cidades mencionadas, cuja distância entre si é de aproximadamente $20 \mathrm{~km}$.

A Formação Pirambóia constitui-se por arenitos de cores rosadas, maciços ou com estratificações plano paralelas e cruzadas, pouco argilosos (menos de $10 \%$ de argila), com mais de $75 \%$ de areia. O diâmetro médio corresponde ao da areia fina, a seleção é pobre a muito pobre, assimetria muito positiva e curtose extremamente leptocúrtica. A fração grossa é bem mais selecionada que a fração fina, enquanto o intervalo Q1Q3 é pouco amplo, contendo no máximo 3 classes texturais. $\mathrm{O}$ valor da mediana é bastante uniforme, concentrando-se na areia fina, a exemplo do limite das admisturas. No contato com a Formação Corumbataí, a Formação Pirambóia apresenta uma camada de arenito grosseiro; no entanto, esse contato é difícil de ser observado por ocorrer ao longo de encostas ou estar afetado por intrusões de diabásio. A ocorrência da Formação Pirambóia restringe-se a toda a parte norte da folha e sua espessura máxima aflorante é de $120 \mathrm{~m}$ nos arredores de Jacirendi.

Os sedimentos da Formação Piraçununga ocupam quase toda a área localizada na margem esquerda do rio Mogi-Guaçu, e o alto dos interflúvios situados a leste-nordeste de Porto Ferreira. São representados por areias argilosas, sem estruturas sedimentares, com espessuras de até $15 \mathrm{~m}$, apresentando na base uma linha de seixos ou cascalheira compostos por quartzo, quartzito e pedaços de limonita. Sua composição granulométrica apresenta, em geral, 50 a $70 \%$ de areia, 20 a $35 \%$ de argila e menos que $10 \%$ de silte. $\mathrm{O}$ diâmetro médio é equivalente à classe do silte grosso, a seleção é pobre a muito pobre, assimetria muito positiva e curtose muito platicúrtica. A fração grossa é bem selecionada, apresentando diâmetro ligeiramente superior ao da fração grossa da Formação Pirambóia. O intervalo Q1-Q3 é o mais am- plo entre as unidades geológicas estudadas, contendo de 5 a 7 classes granulométricas. A fração fina concentra-se entre silte fino e argila, tendo uma seleção pior que a da fração grossa. Os valores da mediana são semelhantes aos encontrados para a Formação Pirambóia, situando-se entre as frações areia fina e areia muito fina, pouco afastados do limite das admisturas.

Os depósitos recentes constituem as planícies aluviais dos rios Mogi-Guaçu e Jaguari-Mirim, dentre os principais. São formados por areias e argilas que são economicamente exploradas.

As intrusões de diabásio são bastante representativas. Entre Santa Cruz das Palmeiras e a Cachoeira de Emas aflora extenso lacólito de diabásio que atinge espessura de até $150 \mathrm{~m}$ naquela cidade. Posiciona-se entre a Formação Corumbataí e o Grupo Tatuí. No vale do rio Claro o diabásio constitui uma soleira com espessura de $70 \mathrm{~m}$, intrusão essa situada na parte basal da Formação Pirambóia e que tem continuidade em direção sudeste, onde se confunde com a intrusão de Santa Cruz das Palmeiras.

Em subsuperfície ocorrem duas grandes intrusões básicas em Porto Ferreira e Piraçununga: nesta o diabásio tem $95 \mathrm{~m}$ de espessura e está intercalado entre as Formações Corumbataí e Irati; naquela a intrusão está sob (ou entre) a Formação Irati e tem uma espessura superior a $125 \mathrm{~m}$.

$\mathrm{Na}$ parte norte da folha ocorrem diques de diabásio associados a falhas, constituindo corpos alongados salientes na topografia.

As falhas apresentam direções noroestesudeste, nordeste-sudoeste e norte-sul; afetam principalmente o contato entre as Formações Pirambóia e Corumbataí, elevando os blocos contendo os sedimentos permianos com rejeitos de até $80 \mathrm{~m}$.

A direção das camadas é de $\mathrm{N} 25^{\circ} \mathrm{W}$ e o mergulho $1 / 2^{\circ} \mathrm{SW}$. 
MAPA GEOLÓGICO

DA FOLHA DE PIRACUNUNGA

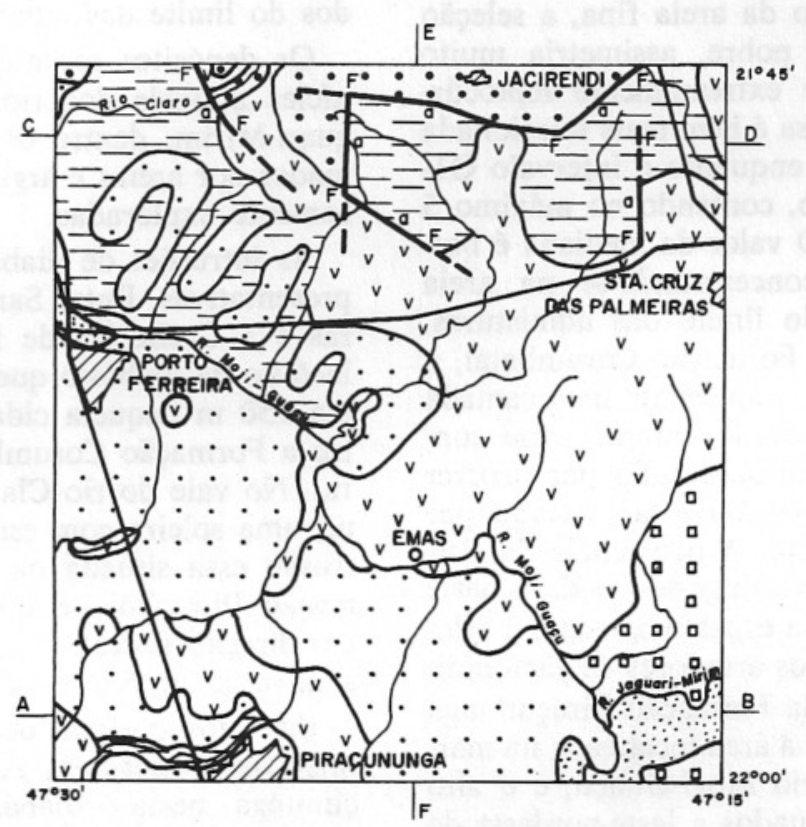

LEGENDA

प्D CIDADE

RODOVIA

$<$ DRenagem

FO F FALHA

A $B$ SEÇÃo GEOLÓGICA

CONTATO GEOLÓGICO

ESCALA

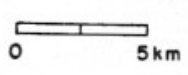

\section{ESTRATIGRAFIA}

QUATERNÁRIO

$\because:$ FORMAÇ̃o PIRAÇUNUNGA

- formação pirambóia

E- FORMAÇÃo CORUMBATAi

a a gRUPO tatuí

$v v$ DIABÁSIO

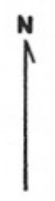

FIG. 1 

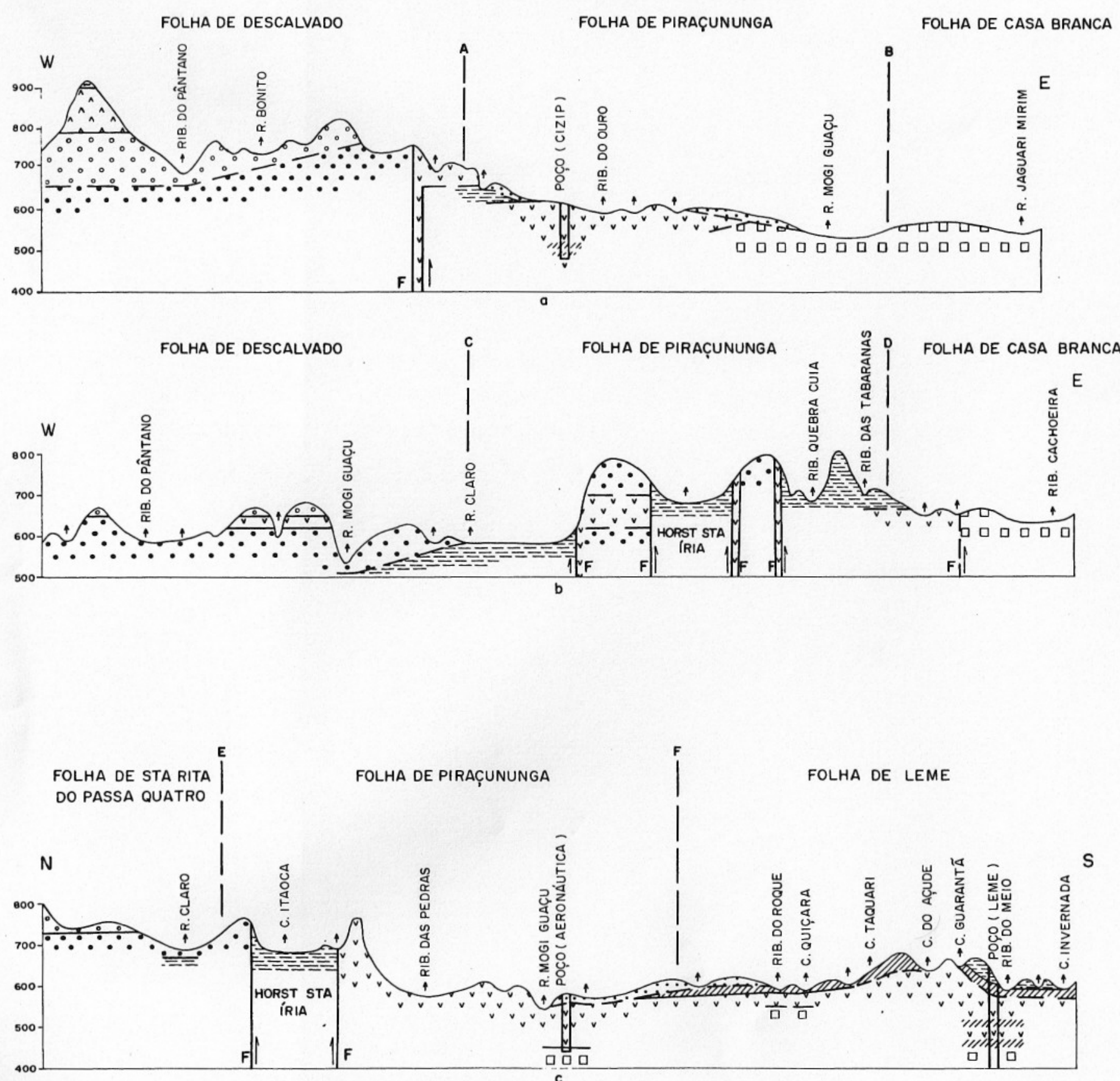

LEGENDA

$::$ FORMAGÃO PIRAÇUNUNGA

$\sim \quad$ GRUPO BAURU

FORMAÇÃO SERRA GERAL

FORMACAO BOTUCATU

.. FORMAC̣ÃO PIRAMBóIA

FORMACTÃO CORUMBATAÍ

IIIT FORMACÃO IRATI

ㅁ SUPER GRUPO TUBARÃO

DV DIABÁSIO

Fil FALHA

Poço

ESCALA VERTICAL

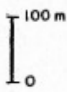

ESCALA HORIZONTAL

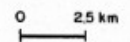

EXAGERO: 25 
SONDAGENS NA ÁREA

PERFIS

PORTO FERREIRA

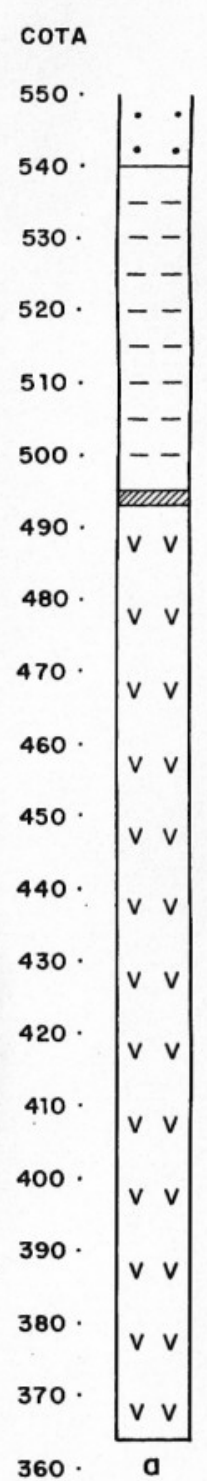

PIRAÇUNUNGA

\begin{tabular}{|c|c|}
\hline COTA & CIZIP \\
\hline 590 . & Iv v \\
\hline 580. & $v v$ \\
\hline 570. & $v v$ \\
\hline 560. & $v v$ \\
\hline 550. & v v \\
\hline 540. & $v v$ \\
\hline $530^{\circ}$ & \\
\hline $520^{\circ}$ & $v v$ \\
\hline 510. & $\mathrm{v} v$ \\
\hline 500. & $v v$ \\
\hline 490. & v v \\
\hline 480. & v v \\
\hline & \\
\hline
\end{tabular}

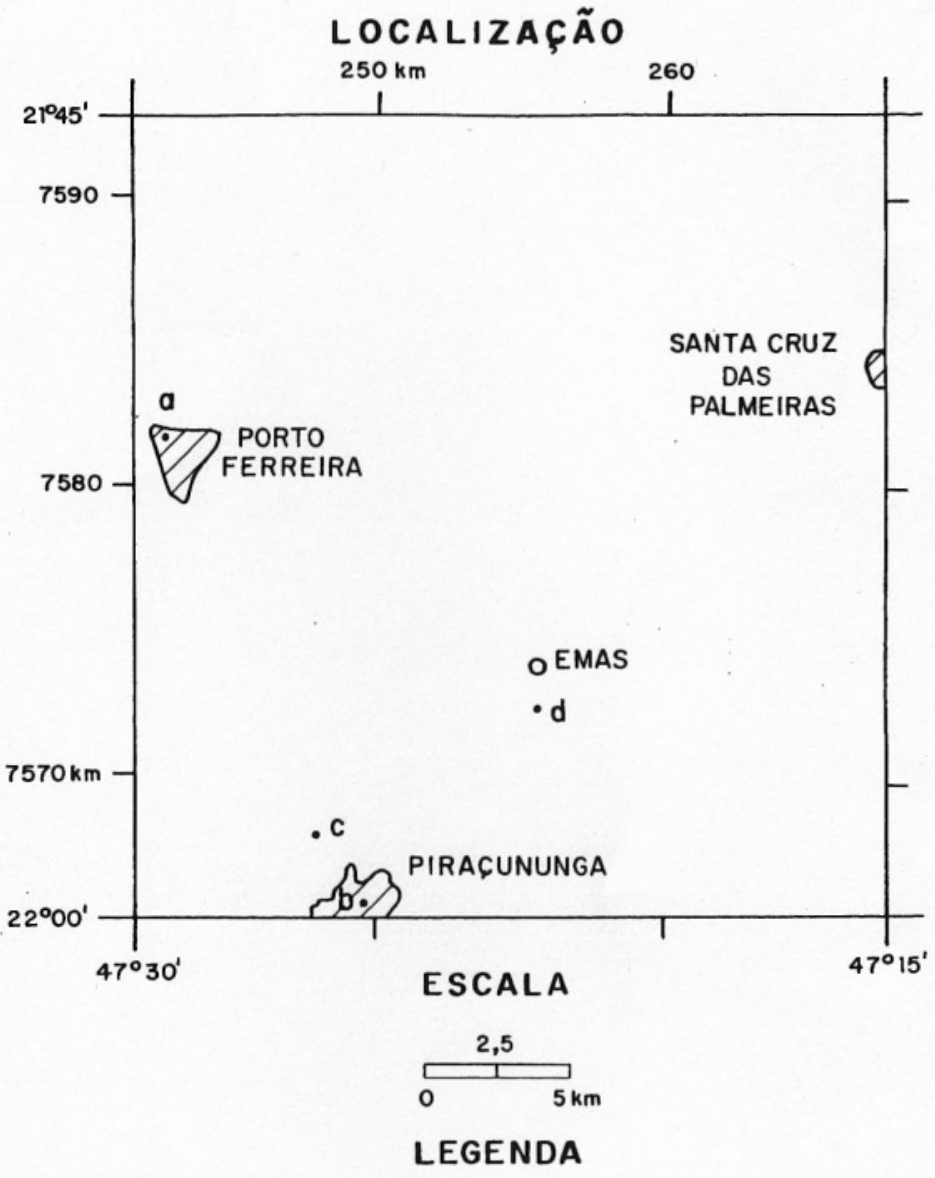

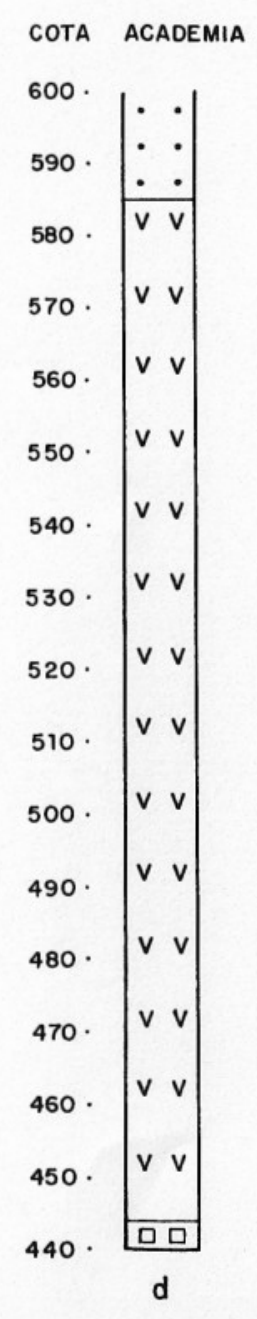

CENOZóico

- F.corumbataí

F. IRATI

SD SUPER GR. TUBARÃO

v v DIABÁSIO

a SONDAGEM 


\section{ATITUDE DAS CAMADAS}

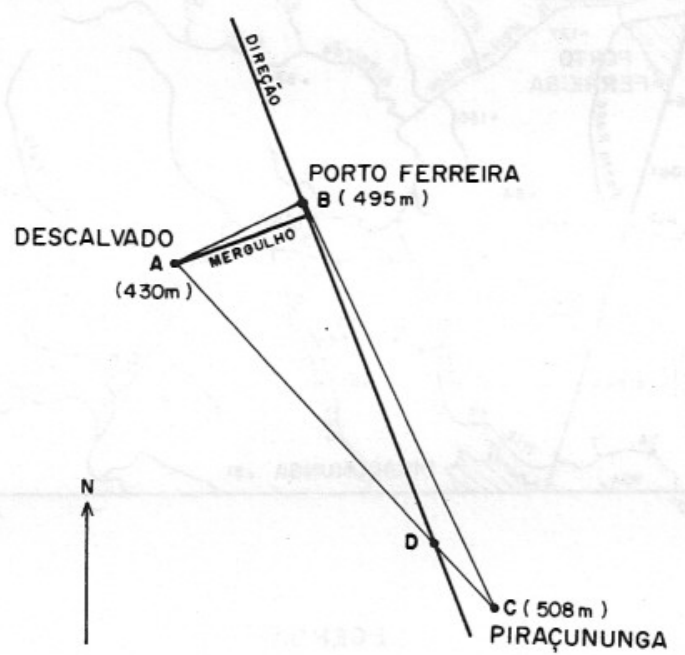

A,B,C - SONDAGEM, COM A COTA DO TOPO DA FORMAÇÃO IRATI

DIRECุÄO $=\mathrm{N} 25^{\circ} \mathrm{W}$.

MERGULHO $=\frac{\eta^{\circ}}{2} \mathrm{SW}$.

\section{ESCALA}

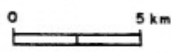

FIG. 4 


\section{MAPA DE LOCALIZACÃ̃O \\ DAS AMOSTRAS}

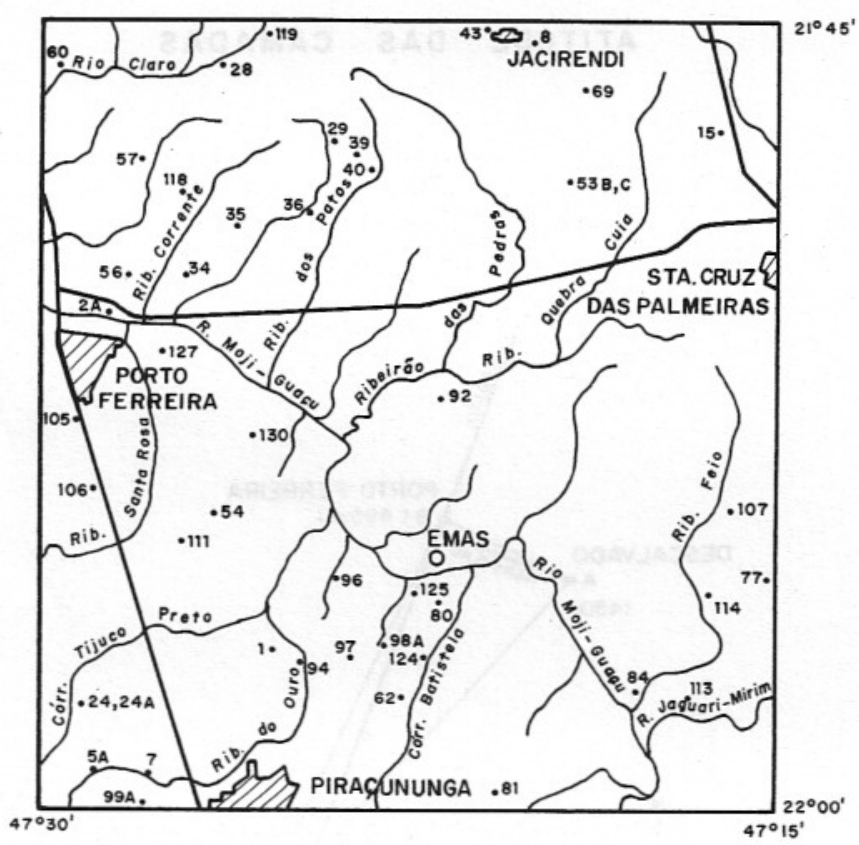

\section{LEGENDA}

DIDADE

RODOVIA

$<$ drenagem

60 AMOSTRA
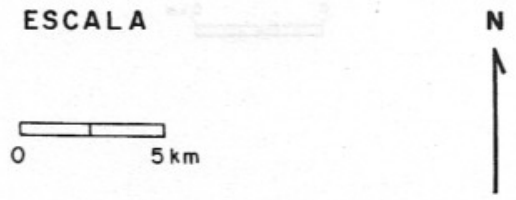

FIG. 5 


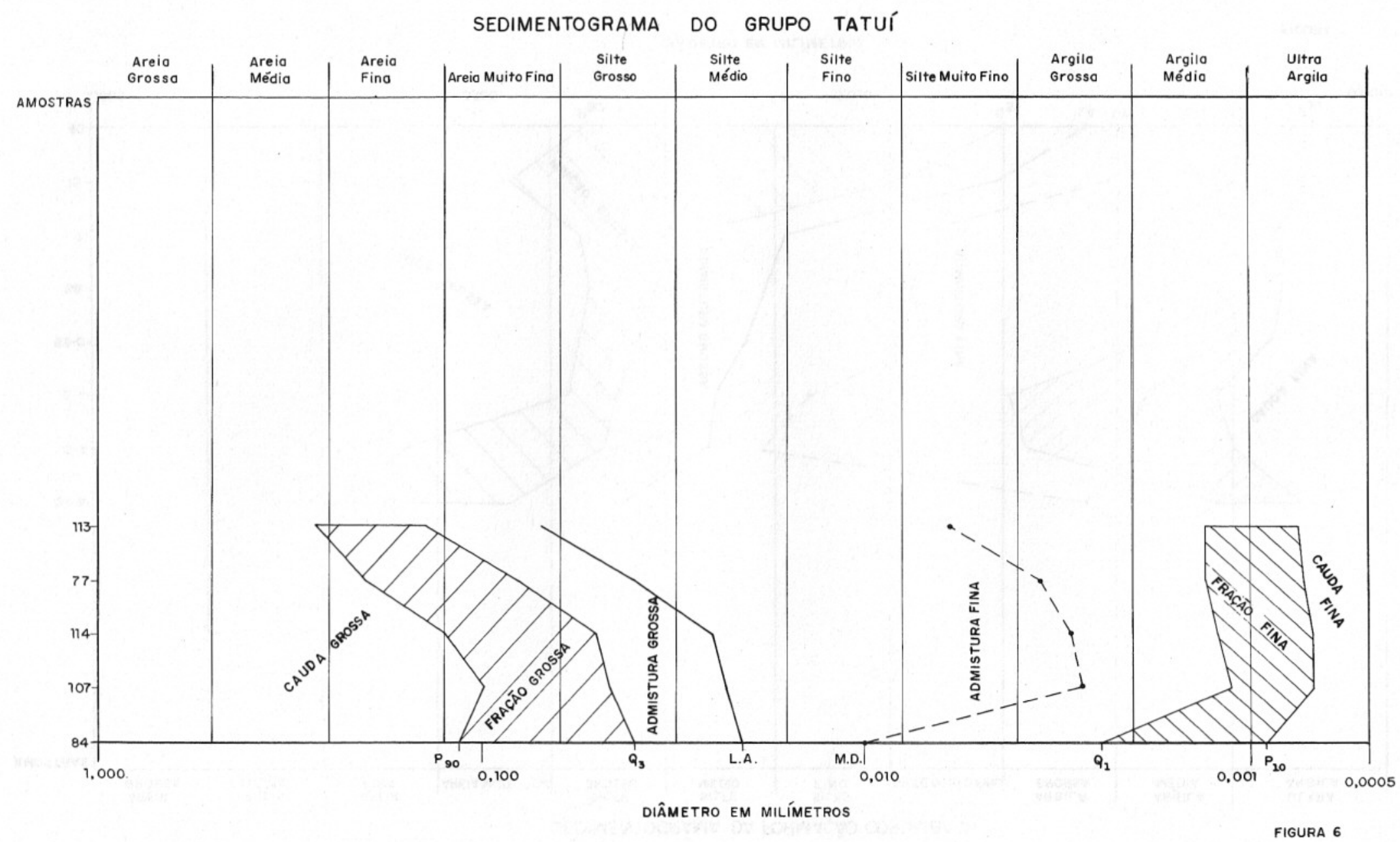


SEDIMENTOGRAMA DA FORMAÇÃO CORUMBATAÍ

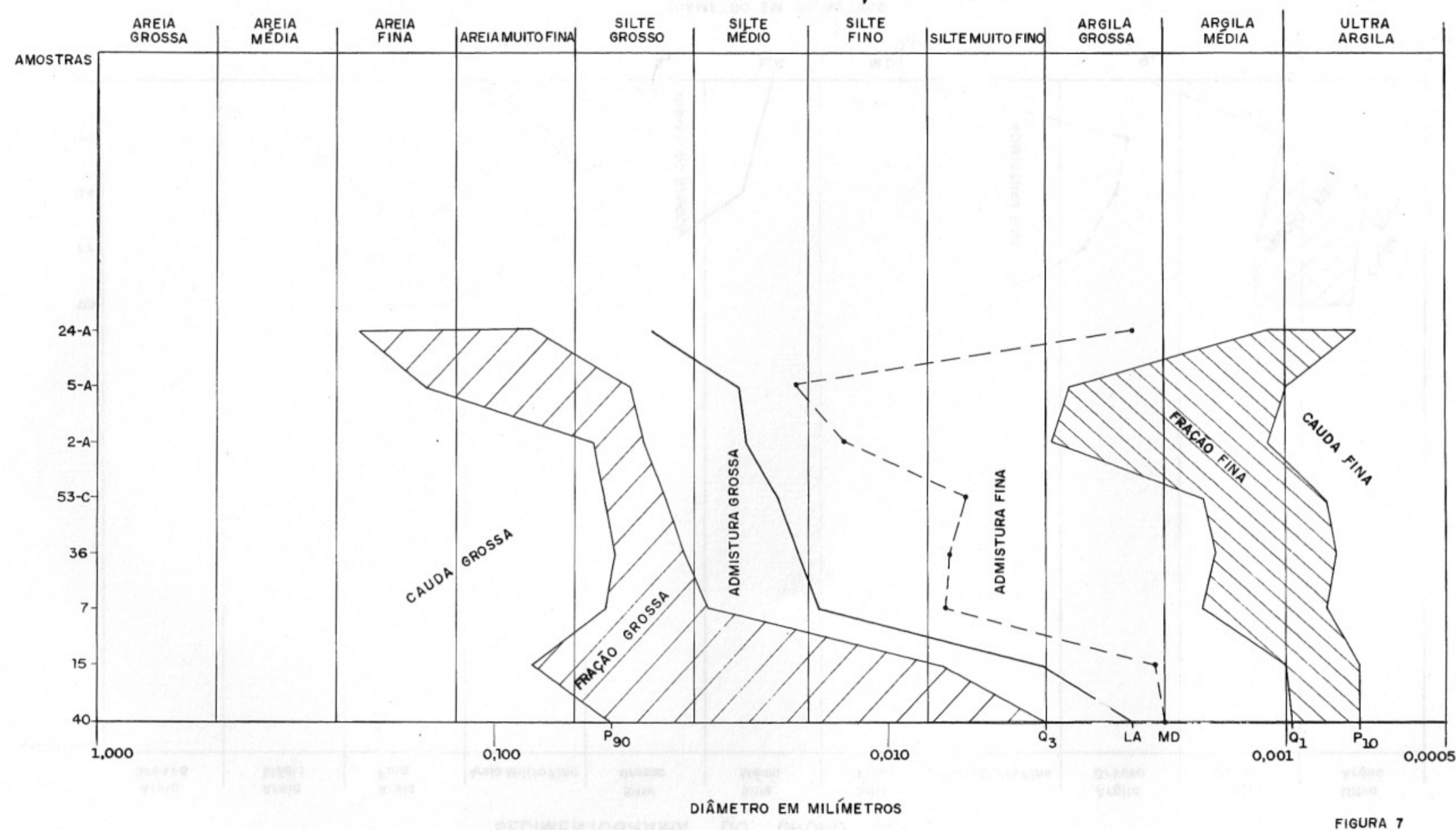


SEDIMENTOGRAMA DAFORMAÇÃO PIRAMBÓIA

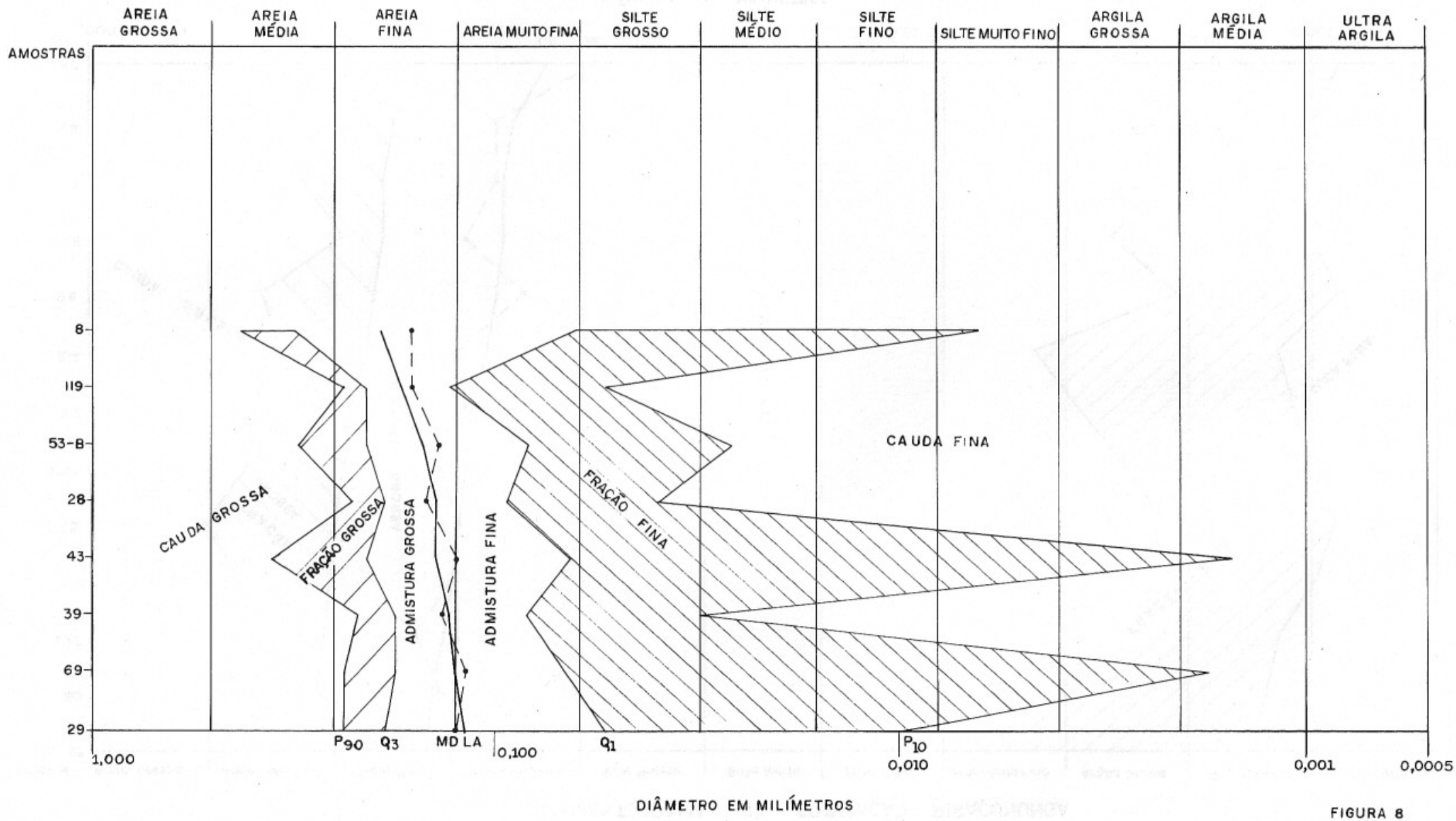


SEDIMENTOGRAMA DA FORMAÇĀO PIRAÇUNUNGA

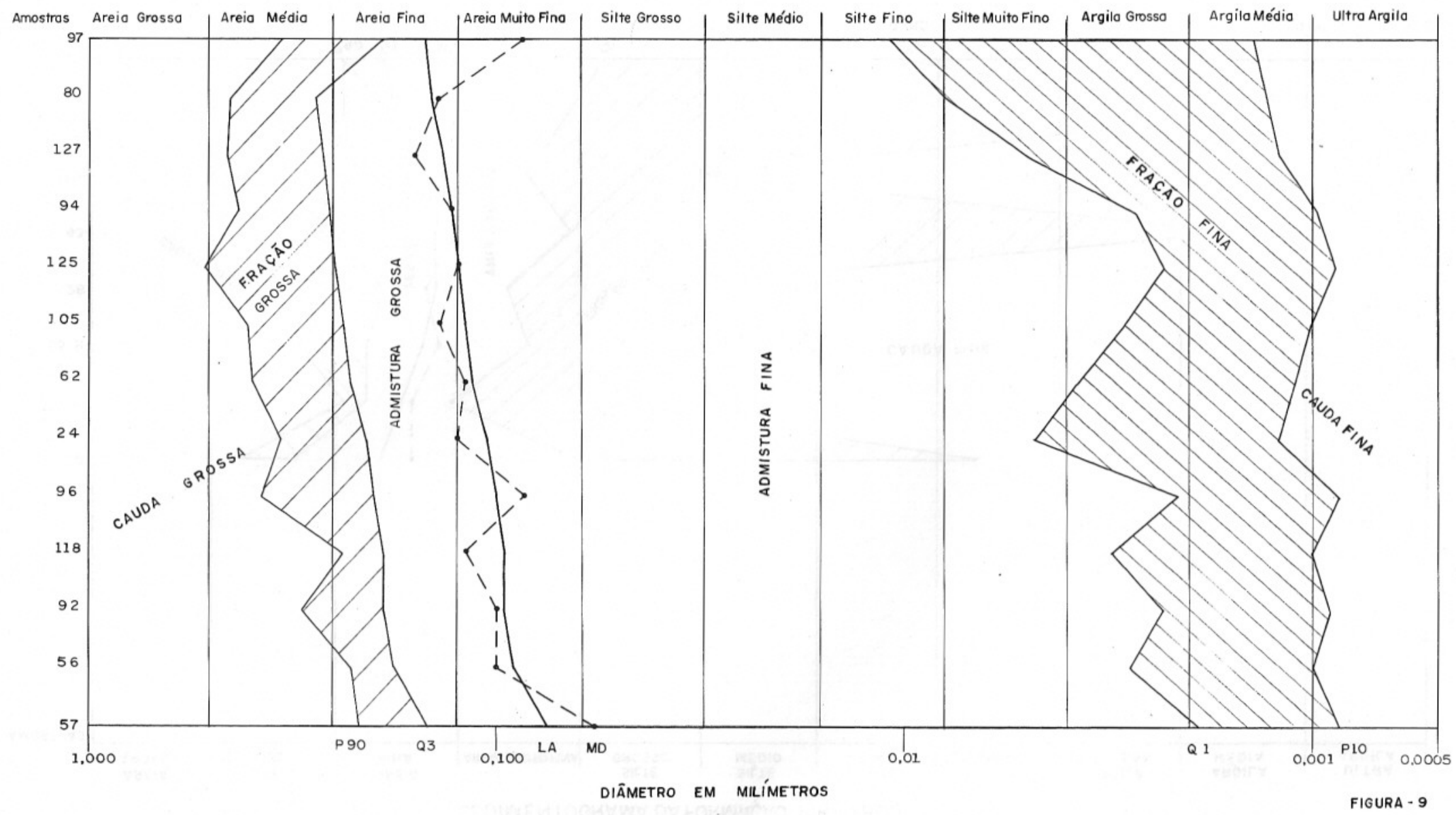




\section{REFERÊNCIAS BIBLIOGRÁFICAS}

ALMEIDA, F.F.M. - 1964 - Fundamentos geológicos do relevo paulista. In: SÃO PAULO. INSTITUTO GEOGRÁFICO E GEOLOGICO. Geologia do Estado de São Paulo. São Paulo, p.169-263. (Boletim, 41)

ANDRADE, S.M. de \& SOARES, P.C. - 1971 - Mapa geológico de semidetalhe do centro leste de São Paulo; bacia do Paraná./Rio de Janeiro/PETROBRÁS DESUL. Escala 1: 100.000. (Relatório, 407 Anexo 18 Folha SF. 23-G-IV)

FREITAS, R.O. de - 1973 - Geologia e petrologia da Formação Caiuá no Estado de São Paulo. São Paulo, Instituto Geográfico e Geo. lógico. 122p. (Boletim, 50)

- 1982 - Definição estratigráfica do Grupo Bauru por sedimentogramas. São Paulo, Instituto Geológico. $86 \mathrm{p}$. (Boletim, 6)

et alii. - 1979 - Projeto de levantamento geológico de formações superficiais. In: SIMPOSIO REGIONAL DE GEOLO-
GIA, 2., Rio Claro. Atas. São Paulo, Sociedade Brasileira de Geologia, v.2 p.263-277.

MASSOLI, M. - 1981 - Geologia do Município de Santa Rita do Passa Quatro, SP. Revista do Instituto Geológico, São Paulo, 2(2):35-45, jun./dez.

MEZZALIRA, S. - 1965 - Folha Geológica provisória de Casa Branca. São Paulo, Instituto Geográfico e Geológico. Escala 1:100.000. (SF-23-G-400).

- - 1970 - Sobre a ocorrência de xenólitos graníticos em rocha basáltica e diabásio amigdalóide, intrusivos em sedimentos permianos e carboníferos do Estado de São Paulo. Anais da Academia Brasileira de Ciências, Rio de Janeiro, 12(4):717-723, dez.

- 1971 - Contribuição ao conhecimento da geologia de subsuperfície e da paleontologia da Formação Irati, no Estado de São Paulo. Anais da Academia Brasileira de Ciências, Rio de Janeiro, 43:273-336, Supl. 